\title{
PROSES PENGASAPAN DAN KUALITAS IKAN CAKALANG (KATSUWONUS PELAMIS) DAN TUNA SIRIP KUNING (THUNNUS ALBACARES) ASAP DI DESA SINGA KECAMATAN HERLANG KABUPATEN BULUKUMBA
}

\section{THE PROCESS OF SMOKING AND QUALITY OF SKIPJACK (KATSUWONUS PELAMIS) AND YELLOW FIN TUNA (THUNNUS ALBACARES) SMOKE IN SINGA HERLANG DISTRICT, BULUKUMBA REGENCY}

\author{
Siska Putri Utami ${ }^{1)}$, Metusalach ${ }^{1)}$, Nursinah Amir ${ }^{1)}$ \\ ${ }^{1)}$ Program Studi Pemanfaatan Sumberdaya Perikanan Fakultas Ilmu Kelautan dan Periknan \\ Universitas Hasanuddin
}

Diterima: 18 Maret 2019; Disetujui: 25 April 2019

\begin{abstract}
ABSTRAK
Penelitian ini bertujuan untuk mengetahui proses pengasapan ikan yang dilakukan oleh pengasap ikan di Desa Singa, Kecamatan Herlang, Kabupaten Bulukumba dan menganalisis kualitas Ikan Cakalang dan Tuna Sirip Kuning Asap di Desa Singa Kecamatan Herlang, Kabupaten Bulukumba. Penelitian ini dilakukan dari bulan April sampai Mei 2018. Metode penelitian yang digunakan adalah survei dan evaluasi. Survei dilakukan untuk mengetahui proses pengasapan dan melihat seluruh kegiatan yang dilakukan oleh pengolah ikan asap yang ada di Desa Singa Kecamatan Herlang Kabupaten Bulukumba. Evaluasi untuk mengetahui kualitas organoleptik bahan baku dari produk ikan asap. Data hasil uji organoleptik dianalisa menggunakan uji-t, anova, dan uji tukey dengan menetapkan tingkat kepercayaan 95\%. Hasil penelitian menunjukkan proses pengolahan ikan asap yang dilakukan oleh masyarakat di Desa Singa menggunakan metode pengasapan panas yang dilakukan secara terbuka dan lama pengasapan yang singkat. Kualitas organoleptik bahan baku ikan cakalang dan tuna sirip kuning setelah dibeli dari penangkap/pelelangan dan sebelum diproses memiliki nilai 8,18 artinya mutu (sangat segar) sesuai dengan SNI 2729:2006, sedangkan kualitas organoleptik bahan baku ikan cakalang dan tuna sirip kuning sesudah pengasapan memiliki nilai 7,2 artinya mutu (segar) sesuai dengan SNI 2725:2013.Ikan cakalang dan tuna sirip kuning asap hanya dapat bertahan 18 - 20 jam disimpan pada suhu kamar, setelah itu produk sudah tidak layak konsumsi.
\end{abstract}

Kata kunci: Asap, cakalang dan tuna sirip kuning, kualitas, pengasapan, tradisional.

\begin{abstract}
This study aimed to determine the process of fish fumigation carried out by fish smokers in Singa, Herlang District, Bulukumba Regency and analyze the quality of skipjack and smoke yellow fin tuna in Singa, Herlang District, Bulukumba Regency. This research is a study cases by survey. This research was conducted from April to May 2018. The survey was conducted to find out the activities of the fumigation process and to see all the activities carried out by fish smokers in the Singa, Herlang District, Bulukumba Regency. Evaluation to know the quality of raw materials used, an organoleptic from smoke fish product. The organoleptic test data were analyzed using t-test, anova, and tukey test by setting a confidence level up to $95 \%$. Search result that the smoked fish processing carried out by the community in Singa, namely the method of fumigation which was
\end{abstract}


carried out openly and the duration of fumigation was short so that it affected the quality and storability of the product. Processed smoked fish products are stored at room temperature and without packaging. The quality of raw materials used an organoleptic of skipjack and yellow fin tuna after being purchased from catchers or auctions and before processing has a value of more than 8,18 meaning quality (very fresh) in accordance with law unsures in SNI 2729:2006, while the quality of raw materials used an organoleptic of skipjack and yellow fin tuna after fumigation has a value 7,2 meaning quality (fresh) in accordance with law unsures in SNI 2725:2013. Skipjack and yellow fin tuna can only last 18 or 20 hours, after which the product is not suitable for consumption.

Keywords: Smoke, skipjack and yellow fin tuna, quality, fumigation, traditional.

\begin{tabular}{ll}
\hline Contact person & $:$ Siska Putri Utami \\
Email & $:$ siskautami343@gmail.com
\end{tabular}

\section{PENDAHULUAN}

Potensi perikanan di Kabupaten

Bulukumba terdiri dari perikanan tangkap (perikanan laut) dan perikanan budidaya (perikanan darat). Dari 10 kecamatan, 7 diantaranya mempunyai potensi kelautan sedangkan potensi perikanan darat terdapat pada semua kecamatan. Produksi perikanan tangkap (perikanan laut) di Kabupaten Bulukumba 5 tahun ini mengalami peningkatan yang cukup signifikan seperti pada tahun 2012 sebesar 32.735 ton, tahun 2013 sebesar 33.094 ton, tahun 2014 sebesar 53.612 ton, tahun 2015 sebesar 52.870 ton, tahun 2016 sebesar 50.072. Peningkatan penangkapan terjadi pada tahun 2012 sampai tahun 2014, kecuali pada tahun 2015 dan 2016 yang mengalami penurunan (DKP Kab. Bulukumba, 2017).

Salah satu cara pengawetan ikan adalah pengasapan. Pengasapan dilakukan melalui beberapa tahap yaitu penggaraman, pengeringan, dan pemanasan. Tujuan pengasapan adalah mengolah ikan agar siap untuk dikonsumsi langsung, memberi cita rasa yang khas agar lebih disukai konsumen, dan memberikan daya awet melalui pemanasan, serta dapat disimpan lebih lama. Pengasapan dapat mengurangi pertumbuhan bakteri, namun selama dan setelah proses pengolahannya kemungkinan kontaminasi bakteri patogen dapat terjadi. Dari catatan Direktorat Jenderal PPM dan PLP Departemen Kesehatan RI menyebutkan penyebab terbanyak dari kasus keracunan makanan yang sering terjadi pada jasa boga adalah dari ikan laut (Yuliawati, 2005).

Metode pengasapan yang digunakan pengasapan panas (Hot smoking) adalah pengasapan yang mengandalkan panas pada prosesnya. Suhu yang digunakan pada jenis pengasapan ini berkisar antara $70^{\circ} \mathrm{C}-100^{\circ} \mathrm{C}$. Waktu yang dibutuhkan dalam pengasapan panas lebih singkat dibandingkan dengan 
pengasapan dingin, yaitu berkisar antara $3-8$ jam. Namun, ikan asap hasil dari proses pengasapan jenis ini mudah rusak karena masih tingginya kadar air yang terkandung di dalamnya (sekitar 60\%). Daya awet ikan asap ini hanya 2 - 3 hari (Adawyah, 2007).

Desa Singa merupakan salah satu desa di Kecamatan Herlang, Kabupaten Bulukumba yang masyarakatnya menggantungkan hidup pada ikan. Hal ini dikarenakan Desa Singa merupakan sentral pengolahan ikan asap. Usaha ini terbentuk dalam kelompok industri rumah tangga (Home Industry) yang terdiri dari berbagai rumah produksi. Usaha ini dijalankan atas dasar kekeluargaan dengan sumberdaya manusia (SDM) merupakan anggota keluarga mereka sendiri.

Pengasapan ikan tersebar dikalangan masyarakat Desa Singa yang dijadikan sebagai usaha. Sebagian penduduk melakukan usaha pengasapan ikan sebagai mata pencaharian yang dilakukan secara turun temurun. Proses pengasapan yang dilakukan masih tradisional dengan menggunakan rumah pengasapan (tungku).
Jenis ikan yang diasap yaitu Ikan Cakalang dan Tuna. Ikan hasil tangkapan berasal dari Sinjai, Bontotiro, dan Tanah Beru. Namun pada proses pengasapan ikan yang dilakukan sering kali tidak sesuai dengan prosedur yang baik sehingga menghasilkan kualitas ikan asap yang tidak bertahan lama.

Berdasarkan permasalahan diatas maka dilakukan penelitian mengenai Proses Pengasapan dan Kualitas Ikan Cakalang (Katsuwonus pelamis) dan Tuna Sirip Kuning (Thunnus albacares) Asap di Desa Singa, Kecamatan Herlang, Kabupaten Bulukumba.

Penelitian ini bertujuan untuk mengetahui proses pengasapan ikan yang dilakukan oleh pengasap ikan di Desa Singa, Kecamatan Herlang, Kabupaten Bulukumba dan menganalisis kualitas ikan cakalang dan tuna sirip kuning asap di Desa Singa Kecamatan Herlang, Kabupaten Bulukumba.

\section{BAHAN DAN METODE Waktu dan Tempat}

Penelitan ini dilaksanakan pada bulan April-Mei 2018 di Desa Singa, Kecamatan Herlang, Kabupaten Bulukumba. 


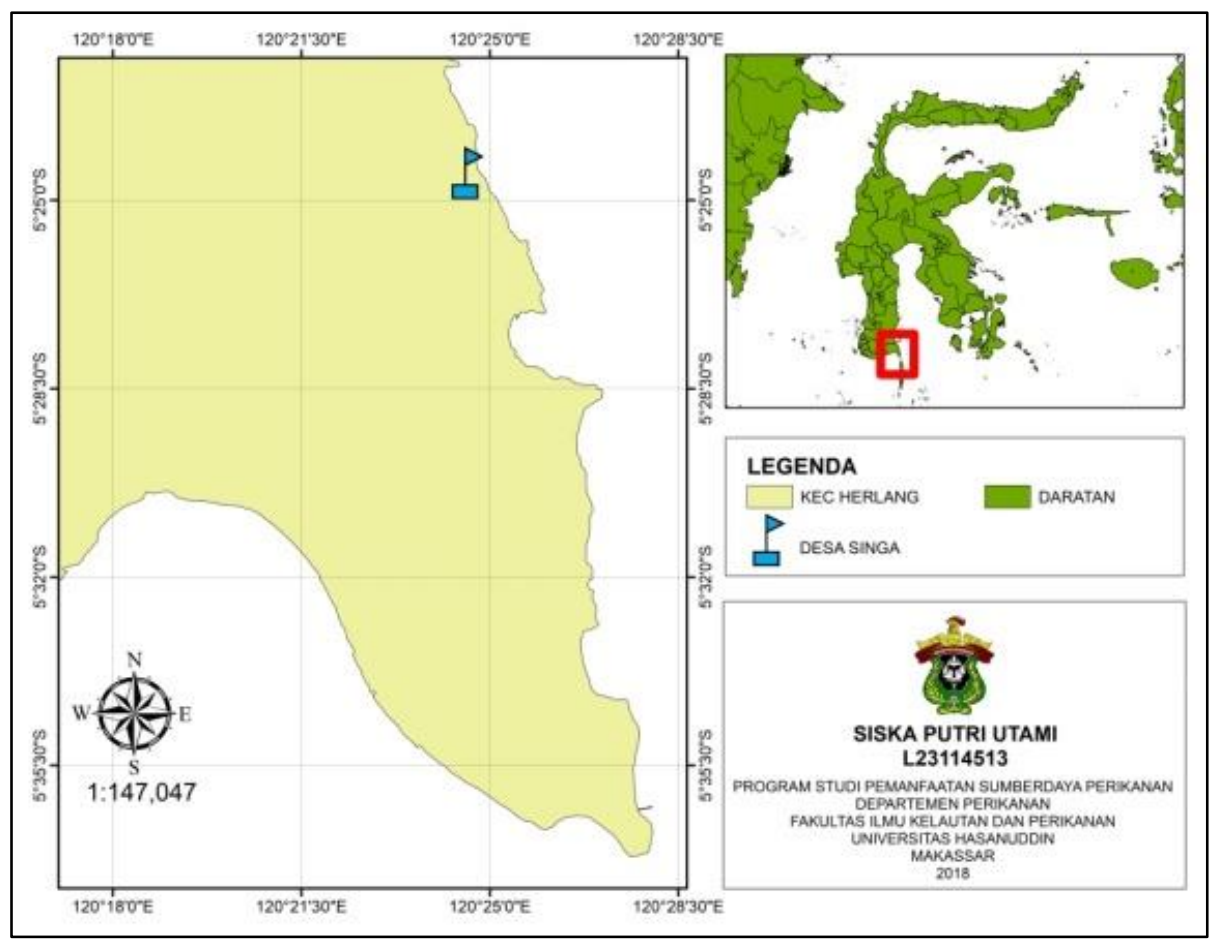

Gambar 1. Peta Lokasi Penelitian

\section{Metode Penelitian}

Penelitian ini merupakan studi kasus untuk mengkaji proses pengasapan dan kualitas ikan cakalang dan tuna sirip kuning secara tradisional di Kabupaten Bulukumba.

1. Prosedur pengambilan data

Data yang dikumpulkan dalam proses pengolahan ikan antara lain terkait dengan:
a. Jenis dan jumlah bahan yang digunakan
b. Cara penyiapan alat dan bahan
c. Fasilitas pengolahan ikan asap
d. Cara pengolahan
e. Uji organoleptik produk ikan segar
f. Uji organoleptik produk ikan asap
g. Cara penanganan setelah pengolahan

\section{Pengujian Organoleptik}

Pengujian organoleptik yang dilakukan menggunakan 2 pengujian yakni pengujian organoleptik terhadap bahan baku dan pengujian terhadap produk olahan, masing-masing menggunakan 5 sampel dengan memberikan penilaian secara rinci melihat tabel (score sheet) dengan menggunakan rentang nilai 1-9. Jumlah panelis yang digunakan adalah 8 orang yang merupakan panelis terlatih.

a) Pengujian Organoleptik Bahan Baku

Pengujian organoleptik bahan baku ikan segar dilakukan 2 kali sesaat setelah ikan dibeli dari penangkap/pelelangan ikan dan sesaat sebelum ikan diolah. Pengujian bahan baku dilakukan dengan menggunakan score sheet dengan SNI 01-2729-1-2006 yang 
meliputi parameter uji organoleptik yakni kondisi mata, lendir permukaan tubuh, bau dan tekstur.

b) Pengujian Organoleptik produk asapan

Pengujian organoleptik produk hasil asapan dilakukan sampai batas penerimaan kualitas produk (tidak layak konsumsi) dengan interval waktu selama 6 jam. Pengujian organoleptik produk ikan cakalang dan tuna dilakukan dengan menggunakan score sheet sesuai dengan SNI 2725:2013 yang meliputi parameter uji organoleptik warna, bau, dan tekstur. Untuk pengujian organoleptik ikan asap dilakukan dengan menggunakan scoresheet sesuai dengan SNI 2346:2011 yang meliputi uji organoleptik kenampakan, bau, rasa, tekstur, jamur, dan lendir.

\section{Analisa Data}

Data yang dikumpulkan terdiri dari data kualitatif dan data kuantitatif. Data kualitatif dideskripsikan dalam bentuk narasi sedangkan data kuantitatif diuji menggunakan uji-t, anova dan uji tukey dan disajikan dalam bentuk tabel dan gambar. Data hasil uji organoleptik dianalisis menggunakan uji-t untuk membandingkan kualitas bahan baku setelah dibeli dan sesaat sebelum diproses untuk pengasapan, anova dan uji tukey untuk membandingkan nilai organoleptik ikan asap antar waktu pengamatan. Perbedaan nyata ditetapkan pada tingkat kepercayaan $95 \%(a=0,05)$.

\section{HASIL DAN PEMBAHASAN}

\section{A. Penerimaan Bahan Baku}

Kesegaran ikan memegang peranan penting dalam menentukan produk ikan asap yang dihasilkan. Pembelian bahan baku ikan yang akan diolah waktu yang diperlukan untuk mencapai TPI itu sekitar 45 menit.

Ikan yang telah dibeli oleh pengolah ikan asap selanjutnya ditimbang, setelah ditimbang selanjutnya ikan dicuci menggunakan air laut yang bertujuan untuk membersihkan ikan dari kotoran dan untuk menjaga kesegaran ikan. setelah dicuci ikan kemudian dipindahkan kebaskom dan ikan diangkut menggunakan mobil Gambar 2.

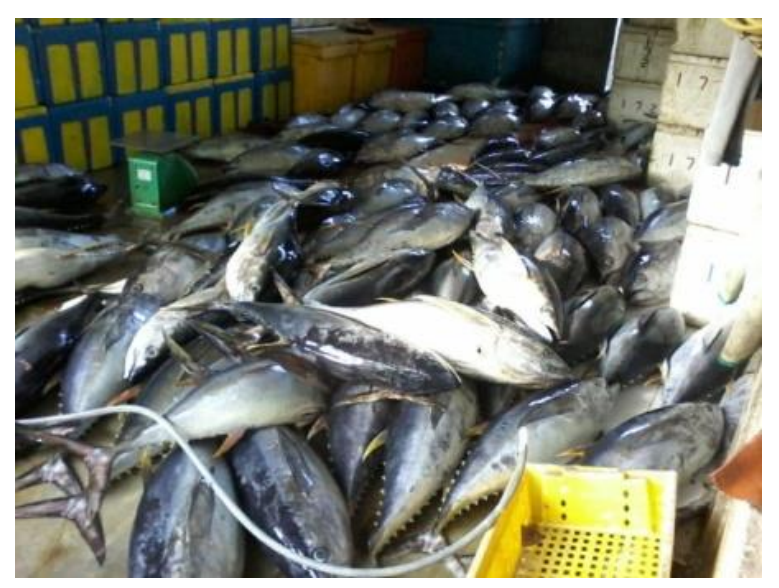

Gambar 2. Kondisi tempat pembelian bahan baku ikan segar

Penanganan dan penempatan ikan secara higienis merupakan persyaratan dalam menjaga ikan dari kemunduran mutu karena 
baik buruknya penanganan akan berpengaruh langsung terhadap mutu ikan sebagai bahan makanan atau bahan baku untuk pengolahan lebih lanjut. Demikian juga penempatan ikan pada tempat yang tidak sesuai, misalnya pada tempat yang bersuhu tinggi, terkena sinar matahari langsung, tempat yang kotor dan lain sebagainya akan mempercepat mundurnya mutu ikan (Diklat, 2010).

\section{B. Persiapan Peralatan dan Bahan}

Alat dan bahan yang digunakan dalam proses pembuatan ikan asap dapat di lihat pada Tabel 1 berikut.

Tabel 1. Alat dalam pembuatan ikan asap di Desa Singa

\begin{tabular}{lc}
\hline Alat & Jumlah alat (unit) \\
\hline Box styrofoam & 2 \\
\hline Parang & 2 \\
\hline Balok & 1 \\
\hline Papan & 1 \\
\hline Baskom & 3 \\
\hline Keranjang & 2 \\
\hline Sikat & 1 \\
\hline Tungku & 1 \\
\hline Para-para & 1 \\
\hline
\end{tabular}

Peralatan yang digunakan dalam proses pengasapan ikan yakni box styrofoam sebagai wadah penyimpanan ikan, parang digunakan sebagai alat pemotong ikan, balok digunakan untuk memukul parang yang berfungsi untuk mempermudah dalam proses pemotongan ikan, papan digunakan sebagai tempat pemotongan ikan, baskom digunakan sebagai wadah pencampuran ikan dengan bahan lainnya, keranjang digunakan sebagai tempat penyimpanan ikan yang sudah diasapi, sikat digunakan sebagai alat membersihkan peralatan, tungku digunakan sebagai tempat pengasapan ikan, para-para digunakan sebagai tempat menyusun ikan saat diasapi.

Bahan yang digunakan dalam pembuatan ikan asap di Desa Singa disajikan dalam Tabel 2.

Tabel 2. Bahan dalam pembuatan ikan asap di Desa Singa

\begin{tabular}{ll}
\hline Bahan & Jumlah \\
\hline Ikan cakalang & $5-8 \mathrm{~kg}$ \\
\hline Ikan tuna sirip kuning & $8-10 \mathrm{~kg}$ \\
\hline Air & 1 baskom \\
\hline Sabut kelapa & 2 karung \\
\hline Serbut kayu & 1 karung \\
\hline
\end{tabular}

\section{Fasilitas Pengolahan Ikan Asap di Desa Singa \\ a. Fasilitas Produksi}

Peralatan pengolahan ikan asap di Desa Singa terdiri dari:

1. Media Pengasapan

Media tempat pengasapan terbuat dari para-para yang terbuat dari bambu. Para-para ini dipasang di atas semen yang sebelumnya dibuat sebagai penopang. Media pengasapan disajikan dalam Gambar 6. 


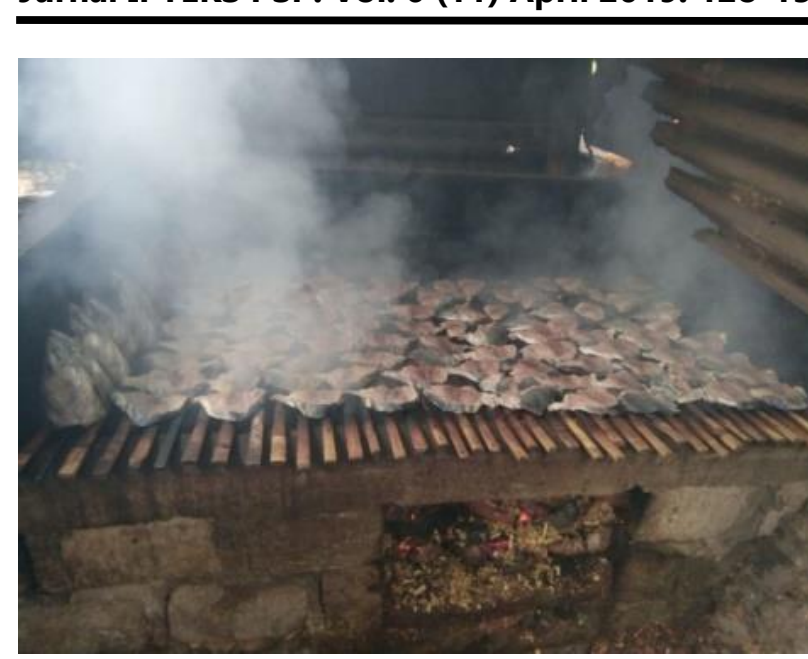

Gambar 3. Media Pengasapan Ikan

\section{Tempat Penyimpanan Ikan Sementara}

Tempat penyimpanan ini berfungsi sebagai wadah untuk penyimpanan ikan. Tempat penyimpanan ini dari lemari pendingin yang sudah rusak. Wadah penyimpanan sementara ini disajikan pada Gambar 4.

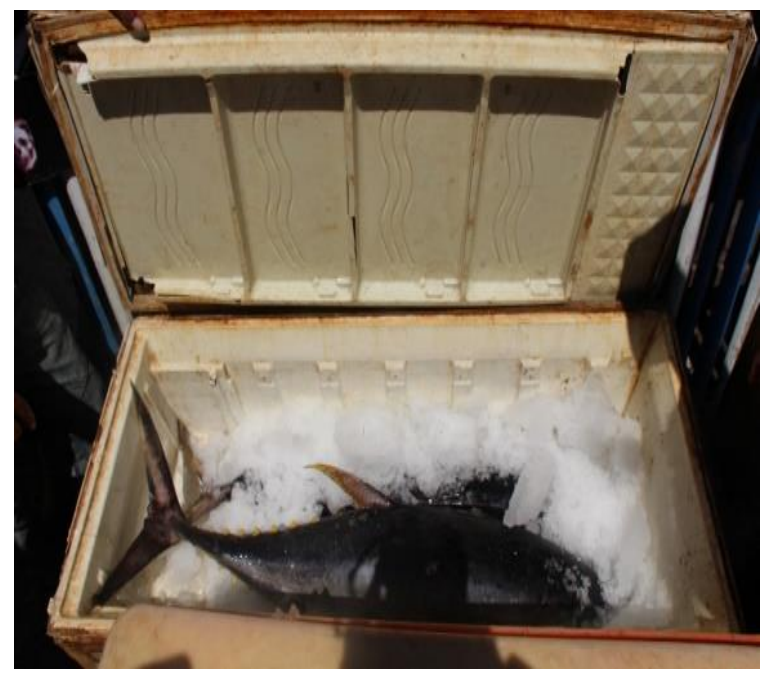

Gambar 4. Tempat Penyimpanan Ikan Sementara

3. Keranjang

Keranjang digunakan sebagai wadah untuk menampung ikan sebelum diasap maupun produk yang siap dipasarkan.
Keranjang yang digunakan pada proses produksi disajikan pada Gambar 5.

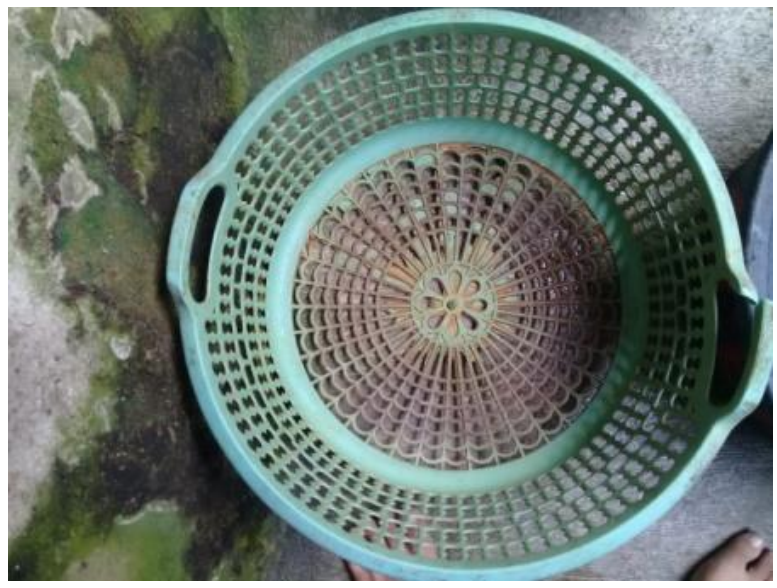

Gambar 5. Keranjang yang digunakan pengrajin pengasapan ikan

4. Sabut kelapa

Sabut kelapa digunakan sebagai bahan bakar utama untuk menghasilkan asap. Sabut kelapa yang digunakan pada proses produksi disajikan pada Gambar 6 .

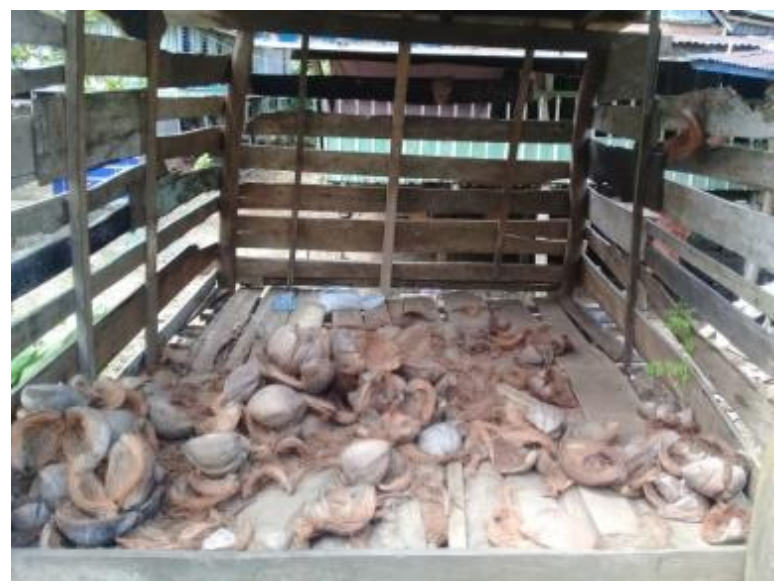

Gambar 6. Sabut dan tempurung kelapa yang digunakan untuk mengasapi ikan

\section{Cara Pengolahan Ikan Asap}

1. Pemilihan bahan baku

Adapun bahan baku yang biasa digunakan oleh masyarakat Desa Singa adalah ikan cakalang (Gambar 10) dan tuna sirip kuning (Gambar 11). Ikan Tersebut dibeli 
langsung dari penangkap atau pedagang ikan yang berlokasi di daerah Sinjai, Bontotiro, dan Tanah Beru.

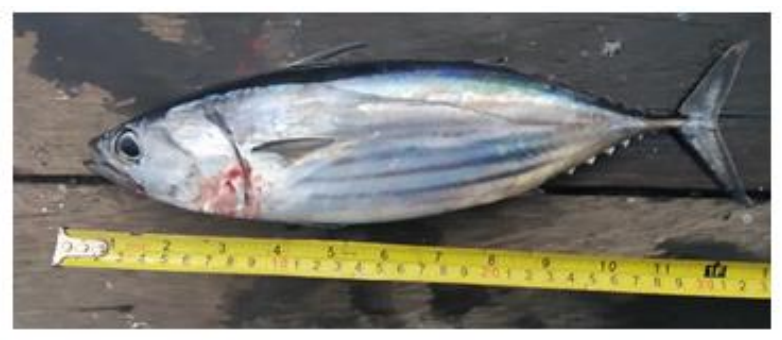

Gambar 7. Ikan Cakalang (Katsuwonus pelamis) Sebagai Bahan Baku Pengasapan Ikan di Desa Singa

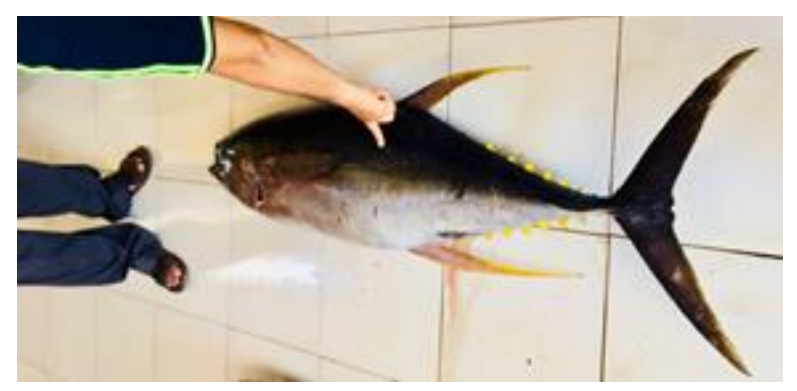

Gambar 8. Ikan Tuna Sirip Kuning (Thunnus albacares) Sebagai Bahan Baku Pengasapan Ikan di Desa Singa

\section{Proses Pemotongan Ikan}

Ikan yang ingin diasapi terlebih dahulu di potong menjadi beberapa bagian seperti pada proses pemotongan kepala ikan dapat disajikan pada Gambar 9.

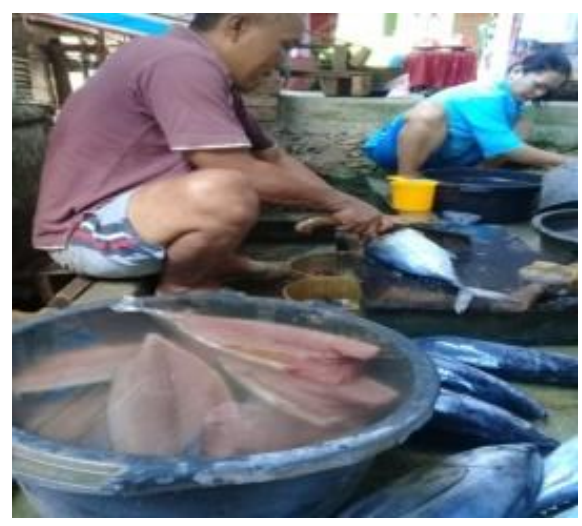

Gambar 9. Proses pemotongan ikan sebelum pengasapan

\section{Proses Pembelahan Ikan}

Setelah pemotongan ikan selanjutnya di belah menjadi menjadi dua bagian kemudian direndam dalam air. Proses pembelahan ikan disajikan pada Gambar 10.

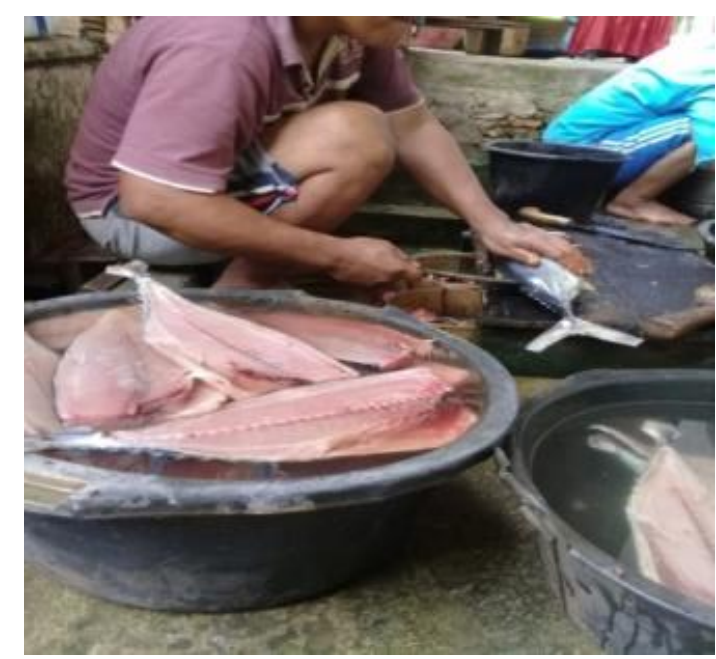

Gambar 10. Proses pembelahan ikan sebelum pengasapan

\section{Penyayatan}

Ikan yang ingin diasapi terlebih dahulu di sayat menjadi beberapa bagian agar komponen asap dapat mencapai bagian dalam daging ikan. ukuran potongan ikan setebal $1-2 \mathrm{~cm}$. Proses disayat ikan disajikan pada Gambar 11.

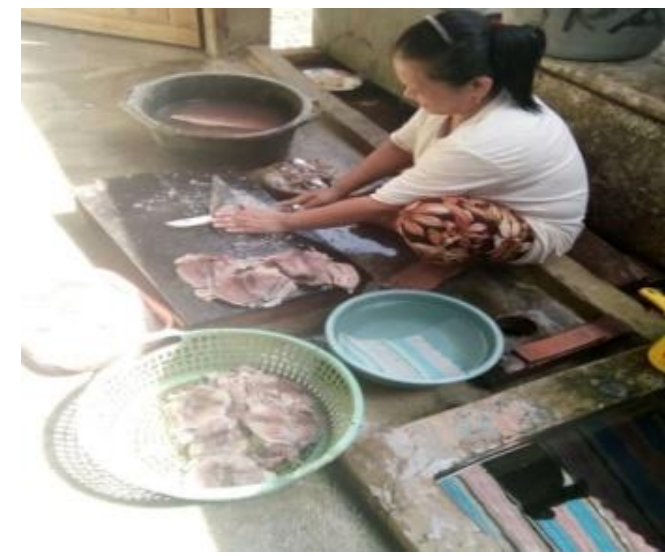

Gambar 11. Proses pemotongan ikan yang akan diasapi 


\section{Pencucian}

Ikan yang sudah di sayat selanjutnya dicuci dalam baskom yang sudah berisi air untuk menghilangkan lendir, darah, pasir, dan kotoran lainnya yang menempel pada potongan ikan. Setelah bersih, ikan kemudian ditiriskan di dalam keranjang atau baskom kering Gambar 15.

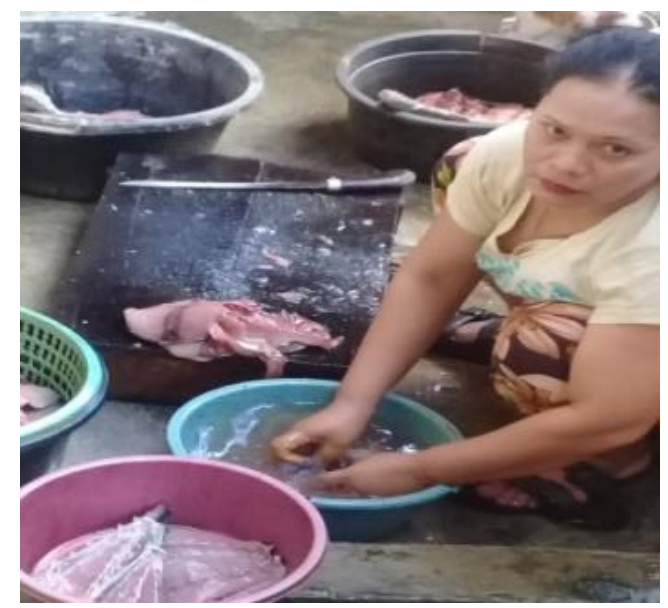

Gambar 15. Pencucian ikan sebelum pengasapan

6. Penirisan

Ikan yang sudah dicuci selanjutnya dipindahkan dalam baskom kemudian disusun rapi lalu ditiriskan. Penirisan ikan disajikan pada Gambar 16.

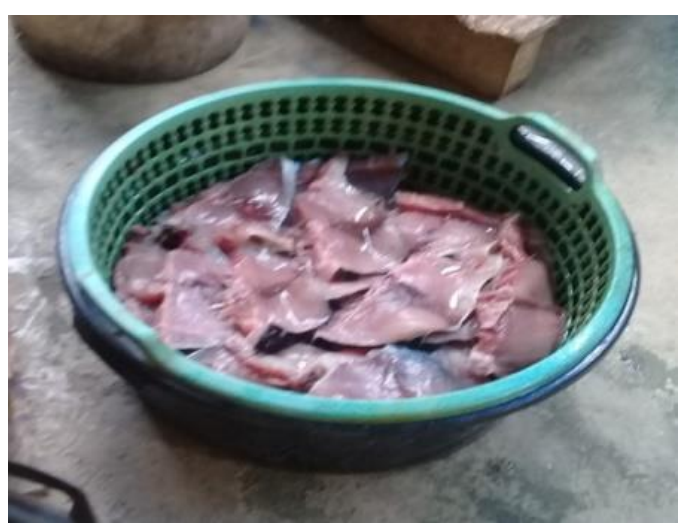

Gambar 16. Penirisan ikan sebelum

\section{Penusukan Ikan}

Setelah ditiriskan selanjutnya ditusuk menggunakan lidi agar pada saat diasapi ikan tidak rusak pada saat proses ikannya di bolak-balik. Setelah diasapi selanjutnya diletakkan dalam keranjang dengan tersusun rapi. Penusukan ikan disajikan pada Gambar 17.

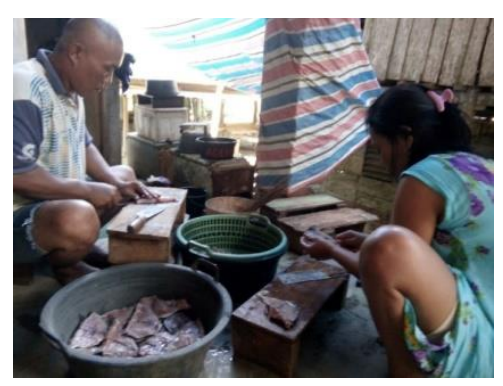

Gambar 17. Penusukan ikan sebelum pengasapan

\section{Pengasapan Ikan}

Tungku pengasapan ikan disiapkan kemudian api dinyalakan dengan cara membakar sabut kelapa. Pada saat sabut kelapa sudah terbakar merata, api dimatikan dan sabut kelapa yang terbakar disebar merata keseluruh bagian dasar tungku. Langkah selanjutnya adalah meletakkan parapara yang terbuat dari bambu di atas tungku kemudian ikan disusun di atas para-para Gambar 18.

pengasapan 


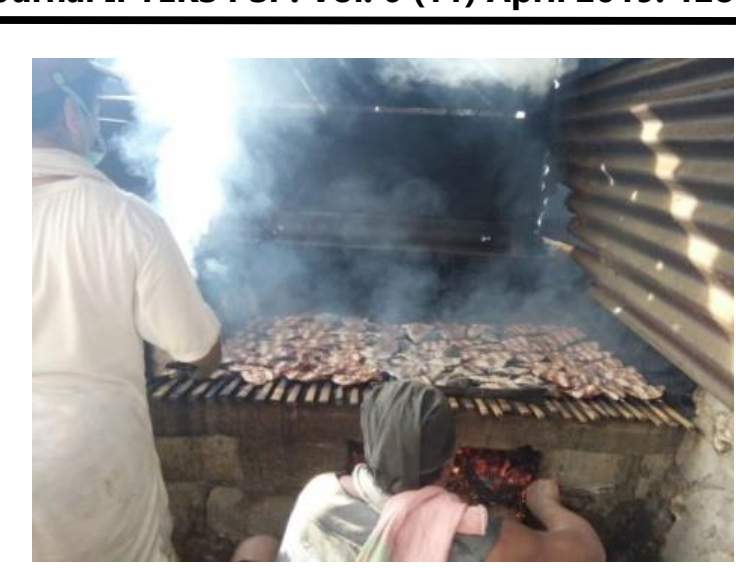

Gambar 12. Proses pengasapan ikan yang dilakukan masyarakat di Desa Singa.

Warna ikan asap kuning ke emasan dan mengkilat sesuai teori yang diungkapkan oleh (Grace, 2010) bahwa warna kuning emas pada ikan asap disebabkan oleh reaksi antara fenol dan oksigen dari udara, yang kemungkinan terjadi setelah unsur asap tersebut mengalami pengendapan saat pengasapan. Sedangkan warna mengkilat pada ikan asap disebabkan lapisan damar tiruan yang dihasilkan oleh reaksi fenol dari golongan pirigalol dengan oksigen dari udara. Komponen karbonil utama dalam asap yang berperan penting adalah fenol.

Proses atau metode pengolahan ikan asap biasanya berbeda antara satu daerah dengan daerah lainnya. Pada pengasapan panas, suhu asap mencapai $120-140^{\circ} \mathrm{C}$ dalam waktu 2-4 jam, dan suhu pada pusat ikan dapat mencapai $60^{\circ} \mathrm{C}$. Pada pengasapan panas ini disamping terjadi penyerapan asap, ikan juga menjadi matang. Rasa ikan asap ini sedap dan berdaging lunak, tetapi tidak tahan lama, dengan kata lain harus dikonsumsi secepatnya Menurut Mahmudy (2014) proses pengasapan dengan metode pengasapan panas dilakukan selama 4 - 5 jam.

Adapun tahapan proses pengasapan ikan di Desa Singa dapat dilihat pada Gambar 13 berikut.

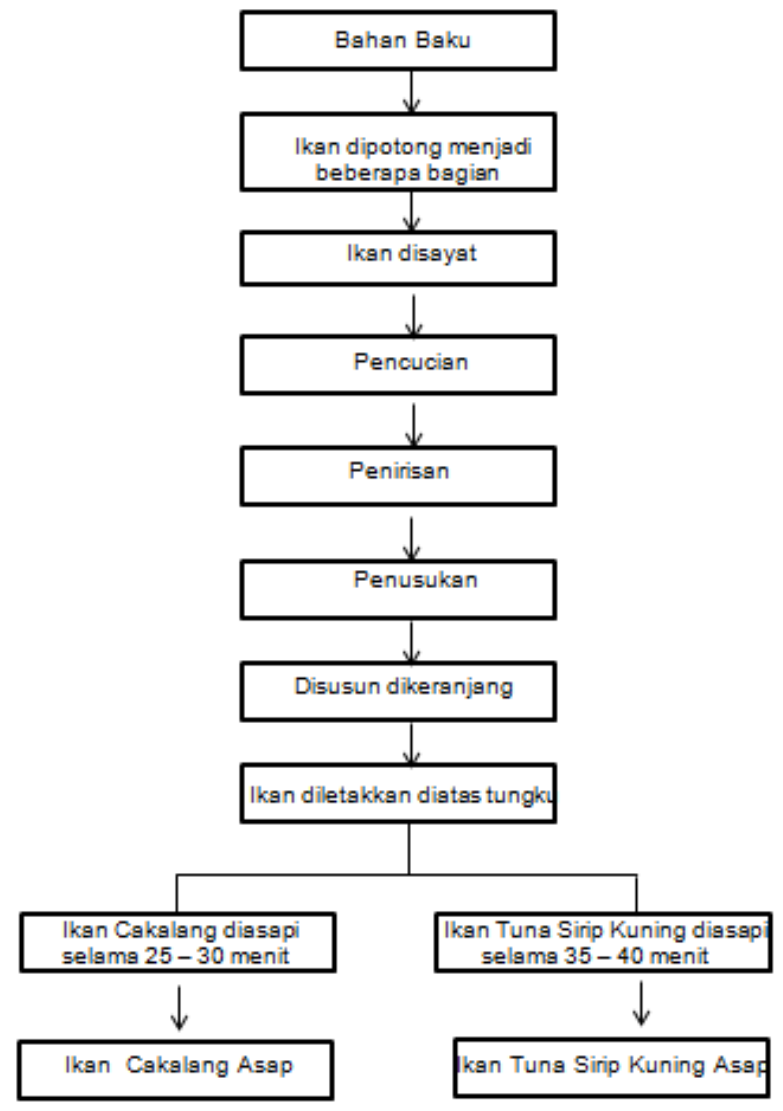

Gambar 13. Diagram alir Proses Pengasapan Ikan Cakalang dan Tuna Sirip Kuning di Desa Singa.

Bahan baku ikan yang digunakan di Desa singa setiap mengolah kapasitas ikan yang digunakan untuk ikan cakalang biasanya 3 - $4 \mathrm{~kg}$ sedangkan ikan tuna sirip kuning biasanya 8 - $10 \mathrm{~kg}$ tergantung dari hasil tangkapan dan musim penangkapan. Ikan 
yang ingin diasapi terlebih dahulu dipotong menjadi beberapa bagian lalu dimasukkan kedalam baskom yang berisi air dan dibiarkan direndam. Setelah proses pemotongan selesai ikan kemudian dibelah menjadi dua bagian kemudian disayat dengan ketebalan $1-2 \mathrm{~cm}$. Pencucian ikan dilakukan dua kali menggunakan wadah baskom lalu disiram air, Setelah dicuci ditiriskan selanjutnya dilakukan penusukan ikan selama 1 jam dan disusun rapi dikeranjang kemudian meletakkan parapara yang terbuat dari bambu di atas tungku kemudian ikan disusun di atas para-para.

Lama waktu pengasapan yang dilakukan masyarakat di Desa Singa untuk ikan cakalang 25 - 30 menit sedangkan ikan tuna sirip kuning 35 - 40 menit. Menurut Karyadi dan Sulistyowati (2010) waktu pengasapan yang singkat berpengaruh pada kesempurnaan proses penguapan air dan senyawa volatile, salah satunya adalah yang menimbulkan bau amis. Oleh karena itu proses pengasapan ikan harus dilakukan dalam waktu yang cukup untuk berlangsungnya reaksi-reaksi perubahan yang diharapkan. Pada proses pengasapan, waktu pengasapan yang hanya 10 menit tidak cukup untuk menghilangkan bau amis. Proses pengasapan yang dilakukan selama 30 menit dapat menghasilkan ikan asap yang tidak amis.
Selama diasapi, ikan di bolak-balik sampai warna merata menjadi kecoklatan. Ikan yang sudah masak dipindahkan ke dalam keranjang. Setelah semua ikan sudah masak selanjutnya ikan disimpan di dalam rumah selama 1 malam sebelum ikan dipasarkan.

\section{E. Sanitasi dan higienis pada pengolahan ikan asap di Desa Singa}

Sanitasi pangan ditujukan untuk mencapai kebersihan yang prima dari tempat produksi, persiapan, penyimpanan, dan penyajian makanan serta air. Hal ini merupakan aspek yang sangat esensial dalam setiap kegiatan penyiapan makanan, khususnya dalam cara penanganan pangan. Program sanitasi dijalankan bukan untuk mengatasi masalah kotornya lingkungan atau kotornya pemrosesan bahan, tetapi untuk menghilangkan kontaminan pada makanan dan mesin pengolahan makanan serta mencegah kontaminasi kembali maupun kontaminasi silang (Winarno dan Surono, 2004).

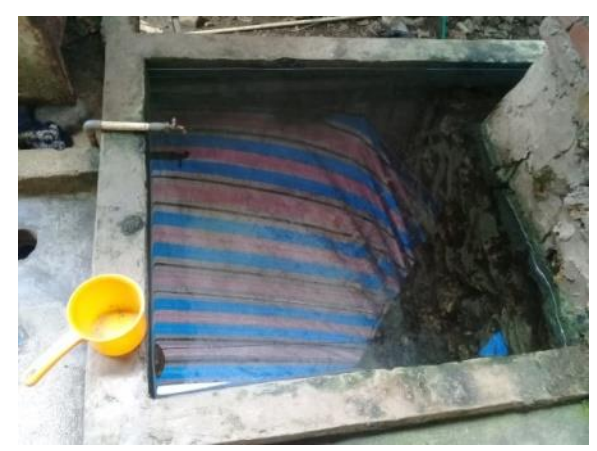

Gambar 14. Air yang digunakan pada saat proses pengolahan ikan asap 
Air merupakan komiditi yang sangat essensial dalam persiapan dan pengolahan pangan. Air ditujukan untuk pengolahan bahan pangan harus bebas dari bakteri patogen (Winarno dan Surono, 2004). Industri rumah tangga ini menggunakan air untuk membersihkan ikan. Air tersebut memiliki ciriciri tidak berbau dan berwarna putih jernih. Air yang digunakan untuk unit produksi tidak dilakukan proses filter terlebih dahulu, selain itu tidak dilakukan juga proses pengendapan, air yang ada langsung digunakan untuk pencucian ikan. unit pengolahan memiliki tendon khusus untuk menampung air yang digunakan pada proses produksi (DKP, 2007).

Permukaan yang kontak dengan produk antara lain keranjang, media pengasapan, dan tangan para kerja. Peralatan yang digunakan dicuci dengan air biasa tanpa menggunakan desinfektan yang dianjurkan, selain itu tidak dilakukan pengujian laboratorium untuk mengetahui cemaran atau kontaminasi pada peralatan yang digunakan. Permukaan bahan yang kontak dengan produk diunit pengolahan harus terbuat dari bahan yang tahan karat, kedap air dengan permukaan yang halus sehingga mudah dibersihkan dan didesinfeksi (DKP, 2007).

Kondisi tempat pengasapan belum dalam kategori bersih dan higienis. Lingkungan sekitar pengolahan banyak berserakan sampah sehingga dikhawatirkan akan mengganggu tingkat higienis ikan asap. Mengenai praktik higienis produsen, mereka mengaku selalu membersihkan peralatan sebelum mengolah akan tetapi berdasarkan dengan pengamatan, mereka hanya sesekali membersihkan peralatan produksi. Mereka mengaku jika sempat mereka baru membersihkanya. Kebiasaan produsen yang tidak memperhatikan tingkat kebersihan lingkungan, peralatan dan bahan baku dapat memberikan dampak bagi konsumen Gambar 15.

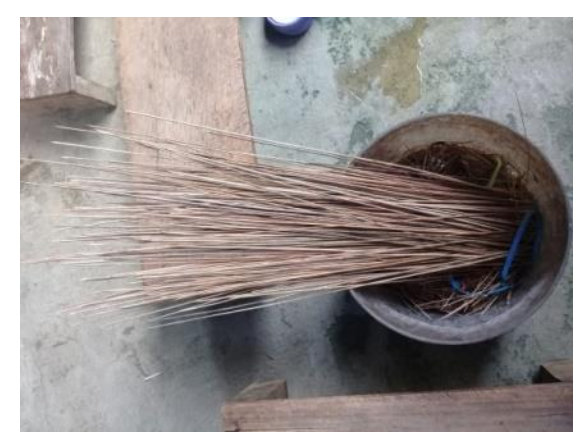

Gambar 15. Kondisi tempat yang digunakan pada pengasapan ikan

\section{F. Uji Organoleptik Bahan Baku Ikan Segar}

\section{a. Ikan Cakalang (Katsuwonus pelamis)}

Penilaian ikan cakalang (Katsuwonus pelamis) secara organoleptik pada penelitian ini meliputi kondisi mata, lendir permukaan tubuh (LPT), bau, dan tekstur dengan nilai sebagai berikut:

1) Kondisi Mata

Kondisi mata ikan cakalang setelah dibeli dari penangkap/pelelangan masih tampak 
cerah, cembung, dan menonjol. Sesaat sebelum diproses kondisi mata sudah berbeda dengan pada saat ikan dibeli (Gambar 16).

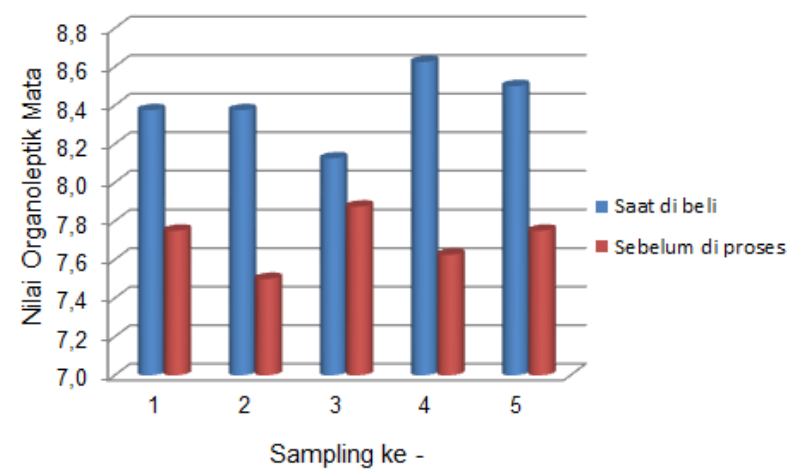

Gambar 16. Nilai organoleptik mata ikan cakalang (Katsuwonus pelamis) bahan baku pengasapan

Berdasarkan gambar di atas, nilai organoleptik mata ikan cakalang saat di beli dari pelelangan/penangkap lebih dari 8,0 yag berarti ikan masih dalam kondisi sangat segar. Sesaat sebelum diproses, nilai organoleptik ikan menurun menjadi 7,5 - 7,8 yang berarti ikan masih segar tetapi sudah mengalami kemunduran mutu. Penurunan nilai kondisi mata seiring dengan lamanya masa simpan tanpa penanganan lanjutan, kondisi mata diduga terjadi karena akibat aktivitas bakteri yang begitu cepat sehingga mata ikan menjadi lebih cepat keruh. Menurut Metusalach (2012) salah satu faktor yang mempengaruhi penurunan mutu ikan yang dipasarkan adalah waktu, semakin lama waktu maka semakin cepat ikan mengalalami proses penurunan mutu. Hasil Uji-t nilai organoleptik mata ikan memperlihatkan bahwa kondisi mata ikan cakalang setelah dibeli dari pelelangan/penangkap dan sebelum diproses memiliki perbedaan yang signifikan $(p<0,05)$.

2) Lendir Permukaan Tubuh (LPT)

Kondisi lendir permukaan tubuh ikan cakalang setelah dibeli dari penangkap/pelelangan kondisi lendir permukaan tubuh tampak mengkilap cerah menandakan ikan masih dalam keadaan segar. Sesaat sebelum diproses untuk pengasapan lendir permukaan tubuh tampak masih mengkilap tetapi sudah mulai kurang cerah yang menandakan ikan sudah kurang segar (Gambar 17).

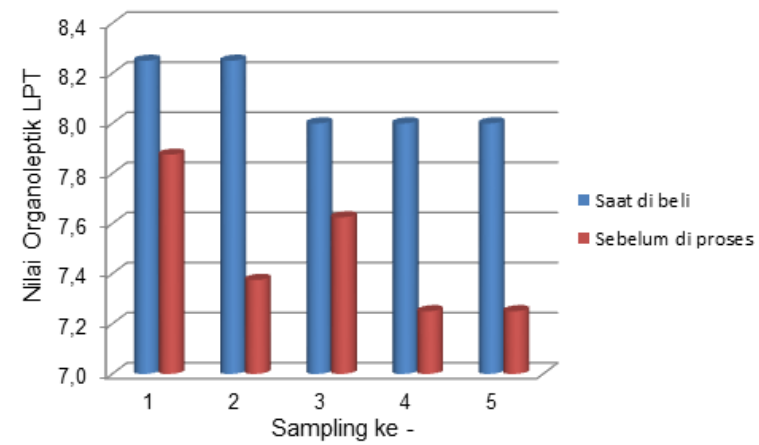

Gambar 17. Nilai organoleptik lender permukaan tubuh ikan cakalang (Katsuwonus pelamis) bahan baku pengasapan

Gambar diatas memperlihatkan bahwa lendir permukaan tubuh ikan cakalang saat dibeli dari pelelangan/penangkap memiliki nilai 8,0 dan cenderung menurun. Sesaat sebelum diproses untuk pengasapan, kondisi 
lendir permukaan tubuh semakin menurun dan memiliki nilai organoleptik 7,3 - 7,9. Semakin lama waktu pengamatan, maka nilai lendir permukaan tubuh semakin menurun. Hal ini sesuai dengan Murniyati dan Sunarman (2000), pada proses pembusukan ikan terjadi tahap hiperaemia yaitu lendir ikan terlepas dari kelenjar-kelenjarnya didalam kulit, membentuk lapisan bening yang tebal disekeliling tubuh ikan. selain itu jika suhu lingkungan naik maka aktivitas bakteri menjadi lebih cepat sehingga membuat pelepasan lendir dari kelenjar menjadi tebal dan keruh. Hasil analisis statistik dengan uji-t nilai organoleptik lendir permukaan tubuh ikan setelah dibeli dari pelelangan/penangkap dan ikan sebelum diproses menunjukkan perbedaan yang signifikan $(p<0,05)$ (Lampiran 3a).

3) Bau

Ikan cakalang setelah dibeli dari penangkap/pelelanganmemiliki kondisi bau spesifik jenis bau air laut menandakan ikan masih dalam keadaan segar. Sesaat sebelum diproses sudah berbeda dengan pada saat ikan dibeli (Gambar 18).

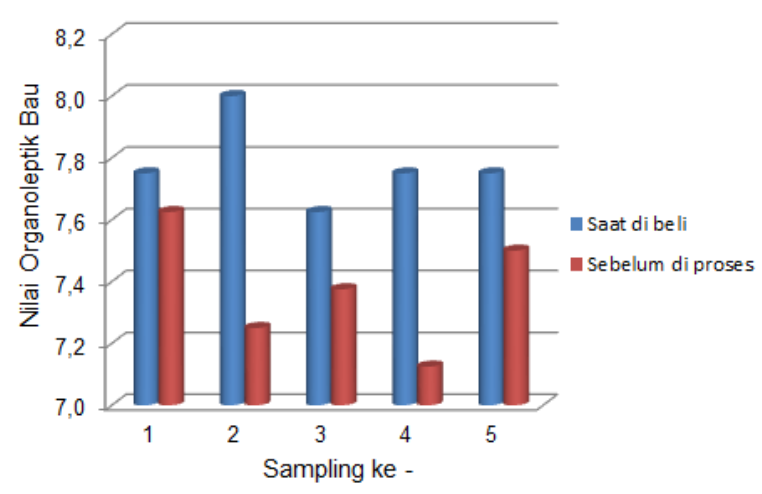

Gambar 18. Nilai organoleptik bau ikan cakalang (Katsuwonus pelamis) bahan baku pengasapan

Gambar diatas memperlihatkan bau ikan cakalang saat dibeli dari pelelangan/penangkap memiliki nilai 7,8. Sesaat sebelum diproses untuk pengasapan, nilai organoleptik bau semakin menurun menjadi 7,1 - 7,6. Salah satu faktor yang mempengaruhi kecepatan penurunan kualitas ikan yakni suhu. Murniyati dan Sunarman (2000) mengatakan bahwa suhu lingkungan yang rendah akan memperpanjang tingkat kesegaran ikan sehingga proses pasca panen ikan harus menerapkan prinsip rantai dingin. Hasil analisis statistik dengan uji-t nilai organoleptik bau setelah dibeli dari pelelangan/penangkap dan sebelum diproses menunjukkan perbedaan yang signifikan $(p<0,05)$.

\section{4) Tekstur}

Tekstur daging ikan cakalang setelah dibeli dari penangkap/pelelangan bila ditekan dengan jari, permukaan tubuh ikan tidak 
membekas menandakan ikan masih segar. Sesaat sebelum diproses tekstur berbeda pada saat dibeli (Gambar 19).

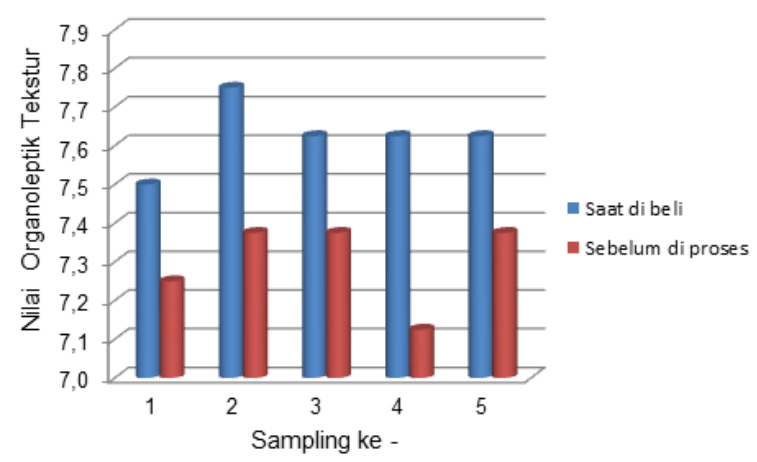

Gambar 19. Nilai organoleptik tekstur ikan cakalang (Katsuwonus pelamis) bahan baku pengasapan

Gambar diatas memperlihatkan tekstur ikan cakalang saat dibeli dari pelelangan/penangkap memiliki nilai 7,6. Sesaat sebelum diproses untuk pengasapan semakin menurun dan memiliki nilai organoleptik 7,1 - 7,4. Menurut Zaitsev dalam Suptijah (2008) adanya proses autolisis yang menyebabkan timbulnya perubahan pada daging ikan, misalnya tekstur daging akan menjadi lunak dan mudah lepas dari tulangnya. Hasil analisis statistik dengan uji-t tekstur setelah dibeli dari pelelangan/penangkap dan sebelum diproses memperlihatkan perbedaan yang signifikan $(p<0,05)$.

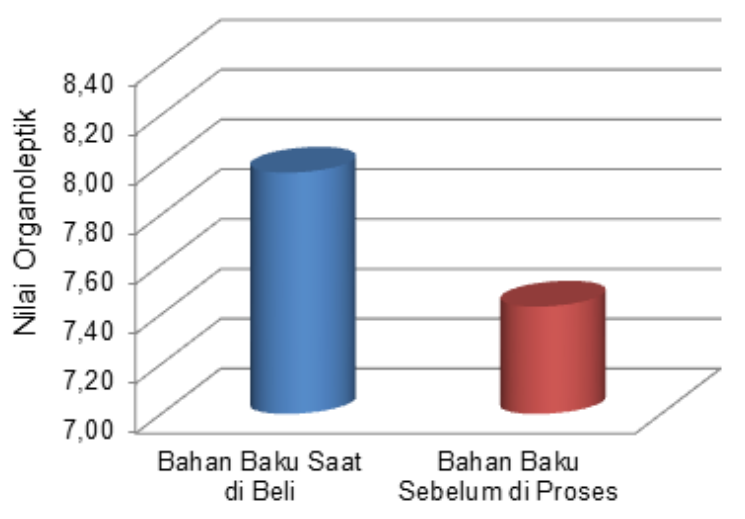

Gambar 20. Nilai rata-rata komponen organoleptik ikan cakalang (Katsuwonus pelamis) bahan baku pengasapan

Gambar 20 diatas memperlihatkan ikan cakalang saat dibeli dari pelelangan/penangkap memiliki nilai 7,97. Sesaat sebelum diproses untuk pengasapan, semakin menurun dan memiliki nilai organoleptik 7,43. Hasil analisis statistik dengan uji-t setelah dibeli dari pelelangan/penangkap dan sebelum diproses memperlihatkan perbedaan yang signifikan $(p<0,05)$.

\section{b. Ikan Tuna Sirip Kuning (Thunnus albacares)}

Penilaian Ikan Tuna Sirip Kuning (Thunnus albacares) secara organoleptik pada penelitian ini meliputi kondisi mata, lendir permukaan tubuh (LPT), bau, dan tekstur dengan nilai sebagai berikut:

1) Kondisi Mata

Kondisi mata ikan tuna sirip kuning setelah dibeli dari penangkap/pelelangan menunjukkan kondisi mata masih tampak 
cerah, cembung, dan menonjol. Sesaat sebelum diproses kondisi mata sudah berbeda dengan pada saat ikan dibeli (Gambar 21).

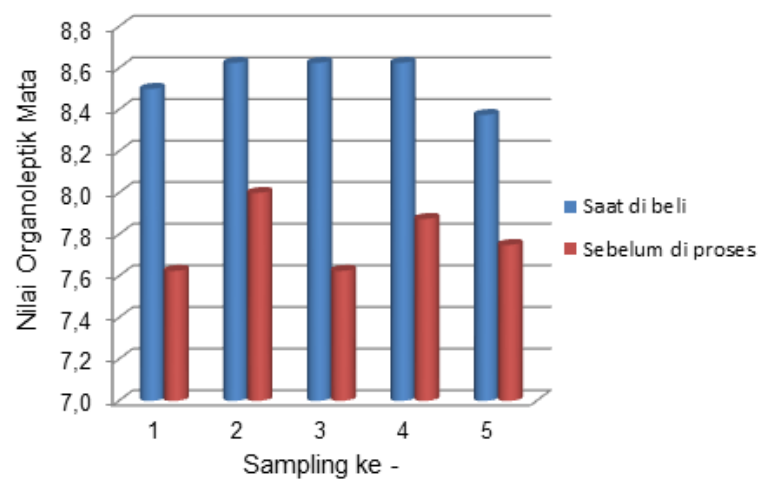

Gambar 21. Nilai organoleptik mata ikan tuna sirip kuning (Thunnus albacares) bahan baku pengasapan

Berdasarkan gambar di atas, nilai organoleptik mata ikan tuna sirip kuning saat di beli dari pelelangan/penangkap lebih dari 8,6 yang berarti ikan masih dalam kondisi sangat segar. Sesaat sebelum diproses nilai organoleptik ikan menurun $7,6-8,0$ yang berarti ikan masih segar tetapi sudah mengalami kemunduran mutu. Penurunan nilai kondisi mata seiring dengan lamanya masa simpan tanpa penanganan lanjutan, kondisi mata diduga terjadi karena akibat aktivitas bakteri yang begitu cepat sehingga mata ikan menjadi lebih cepat keruh. Menurut Metusalach (2012) salah satu faktor yang mempengaruhi penurunan mutu ikan yang dipasarkan adalah waktu, semakin lama waktu maka semakin cepat ikan mengalalami proses penurunan mutu. Hasil uji-t nilai organoleptik memperlihatkan bahwa kondisi mata ikan tuna sirip kuning setelah dibeli dari pelelangan/penangkap dan sebelum diproses menunjukkan perbedaan yang signifikan $(p<0,05)$.

2) Lendir Permukaan Tubuh (LPT)

Kondisi lendir permukaan tubuh ikan setelah dibeli dari penangkap/pelelangan tampak mengkilap cerah menandakan ikan masih dalam keadaan segar. Sesaat sebelum diproses untuk pengasapan lendir permukaan tubuh tampak masih mengkilap tetapi sudah mulai kurang cerah yang menandakan ikan sudah kurang segar (Gambar 22).

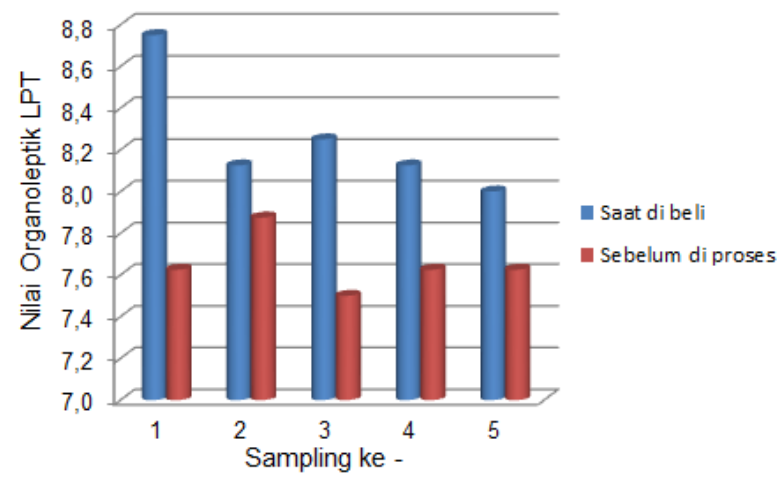

Gambar 22. Nilai organoleptik lender permukaan tubuh ikan tuna sirip kuning (Thunnus albacares) bahan baku pengasapan

Gambar diatas memperlihatkan bahwa lendir permukaan tubuh ikan tuna sirip kuning saat dibeli dari pelelangan/penangkap memiliki nilai 8,0 dan cenderung menurun. Sesaat sebelum diproses untuk pengasapan, kondisi lendir permukaan tubuh semakin menurun dan memiliki nilai organoleptik 7,6 - 
7,9. Hal ini sesuai dengan Murniati dan Sunarman (2000), pada proses pembusukan ikan terjadi tahap hiperaemia yaitu lendir ikan terlepas dari kelenjar-kelenjarnya didalam kulit, membentuk lapisan bening yang tebal disekeliling tubuh ikan. selain itu jika suhu lingkungan naik maka aktivitas bakteri menjadi lebih cepat sehingga membuat pelepasan lendir dari kelenjar menjadi tebal dan keruhHasil analisis statistik dengan uji-t nilai organoleptik lendir permukaan tubuh setelah dibeli dari pelelangan/penangkap dan sesaat sebelum diproses memperlihatkan perbedaan yang signifikan $(p<0,05)$.

3) $\mathrm{Bau}$

Ikan tuna sirip kuning setelah dibeli dari penangkap/pelelangan memiliki kondisi bau spesifik jenis bau air laut menandakan ikan masih dalam keadaan segar. Sesaat sebelum diproses sudah berbeda dengan pada saat ikan dibeli (Gambar 29).

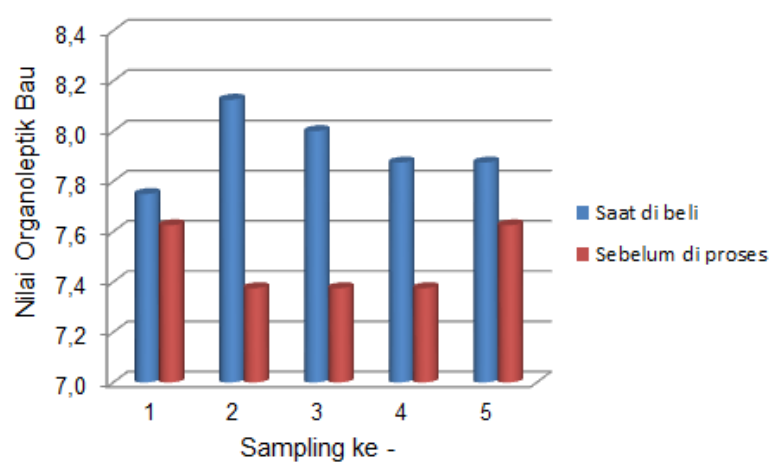

Gambar 23. Nilai organoleptik bau ikan tuna sirip kuning (Thunnus albacares) bahan baku pengasapan
Gambar diatas memperlihatkan nilai organoleptik bau ikan tuna sirip kuning saat dibeli dari pelelangan/penangkap memiliki nilai 7,9. Sesaat sebelum diproses untuk pengasapan, nilai organoleptik bau semakin menurun 7,4 - 7,6. Salah satu faktor yang mempengaruhi kecepatan penurunan kualitas ikan yakni suhu. Murniyati dan Sunarman (2000) mengatakan bahwa suhu lingkungan yang rendah akan memperpanjang tingkat kesegaran ikan sehingga proses pasca panen ikan harus menerapkan prinsip rantai dingin. Hasil analisis statistik dengan uji-t nilai organoleptik bau setelah dibeli dari pelelangan/penangkap dan sebelum diproses menunjukkan perbedaan yang signifikan $(p<0,05)$.

\section{4) Tekstur}

Tekstur daging ikan tuna sirip kuning setelah dibeli dari penangkap/pelelangan, bila ditekan dengan jari, permukaan tubuh ikan tidak membekas menandakan ikan masih segar. Sesaat sebelum diproses tekstur berbeda pada saat dibeli (Gambar 24). 


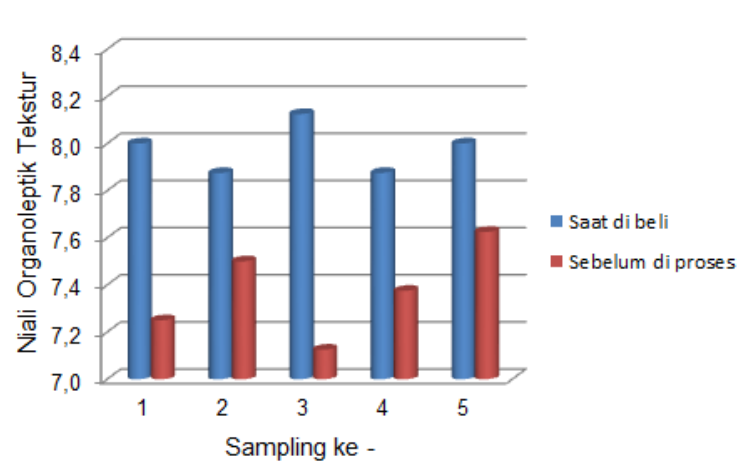

Gambar 24. Nilai organoleptik tekstur ikan tuna sirip kuning (Thunnus albacares) bahan baku pengasapan

Gambar diatas memperlihatkan nilai organoleptik tekstur ikan tuna sirip kuning saat dibeli dari pelelangan/penangkap memiliki nilai 7,9. Sesaat sebelum diproses untuk pengasapan semakin menurun 7,1 7,6. Menurut Zaitsev dalam Suptijah (2008) adanya proses autolisis yang menyebabkan timbulnya perubahan pada daging ikan, misalnya tekstur daging akan menjadi lunak dan mudah lepas dari tulangnya. Hasil analisis statistik dengan uji-t nilai organoleptik tekstur setelah dibeli dari pelelangan/penangkap dan sebelum diproses memperlihatkan perbedaan yang signifikan $(p<0,05)$.

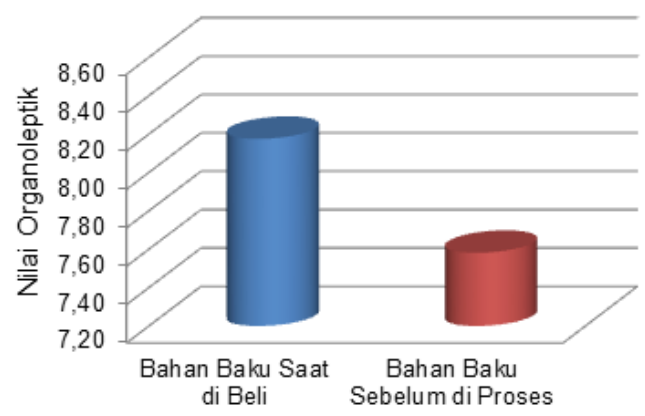

Gambar 25. Nilai rata-rata komponen organoleptik ikan tuna sirip kuning (Thunnus albacares) bahan baku pengasapan
Gambar diatas memperlihatkan ikan tuna sirip kuning saat dibeli dari pelelangan/penangkap memiliki nilai 8,18. Sesaat sebelum diproses untuk pengasapan semakin menurun dan memiliki nilai organoleptik sekitar 7,58. Hasil analisis statistik dengan uji-t nilai organoleptik ikan tuna sirip kuning setelah dibeli dari pelelangan/penangkap dan sebelum diproses memperlihatkan perbedaan yang signifikan $(p<0,05)$.

\section{G. Uji Organoleptik Ikan Asap}

\section{a. Ikan Cakalang (katsuwonus pelamis)}

Penilaian ikan cakalang (Katsuwonus pelamis) asap secara organoleptik pada penelitian ini meliputi kenampakan, bau, rasa, dan tekstur, dengan nilai sebagai berikut:

1) Kenampakan

Berdasarkan

pengamatan kenampakan ikan cakalang asap, kemunduran mutu terjadi secara terus menerus selama waktu penyimpanan produk ikan asap. Parameter kenampakan menurun ke level tidak layak konsumsi setelah 18 jam selesainya proses pengasapan (Gambar 32). 


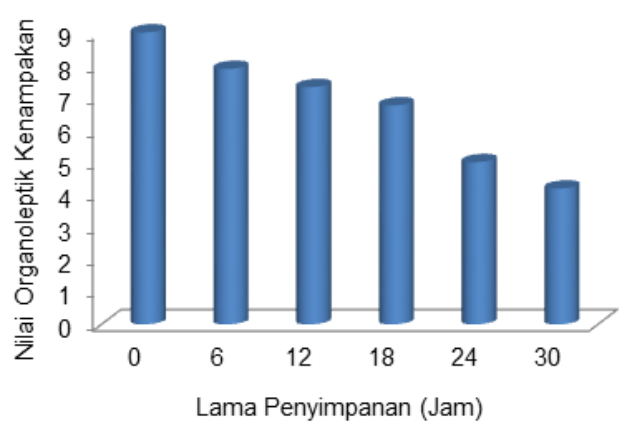

Gambar 26. Nilai organoleptik kenampakan ikan cakalang (Katsuwonus pelamis) bahan baku ikan asap

Berdasarkan gambar diatas, nilai organoleptik kenampakan ikan cakalang asap masih bagus pada penyimpanan 12 jam sesudah pengasapan kualitas ikan asap cukup baik yaitu nilai 7,3 , sesuai dengan Standar Nasional Indonesia (SNI 2725:2013) bahwa nilai organoleptik ikan asap pada lama penyimpanan minimal 7. Hasil anova berdasarkan lama penyimpanan (Lampiran 4) memperlihatkan bahwa nilai organoleptik kenampakan ikan cakalang asap memiliki perbedaan yang signifikan. Hasil uji tukey (Lampiran 4) memperlihatkan bahwa kualitas ikan asap antar jam penyimpanan berbeda secara signifikan $(p<0,05)$ berarti setelah pengasapan kualitas ikan cakalang asap mengalami penurunan secara nyata.

2) Bau

Ikan cakalang asap sesudah pengasapan memiliki spesifikasi bau yang harum dan tanpa bau tambahan mengganggu. Nilai organoleptik bau ikan asap masih memenuhi standar kelayakan konsumsi sampai 18 jam setelah proses pengasapan (Gambar 27).

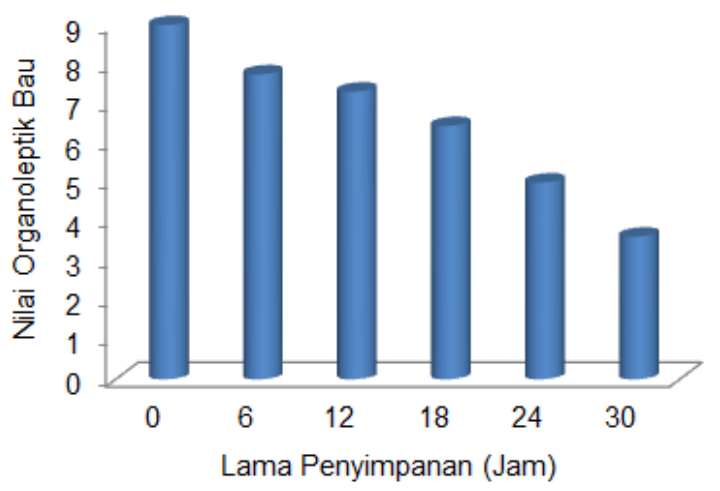

Gambar 27. Nilai organoleptik bau ikan cakalang (Katsuwonus pelamis) bahan baku ikan asap

Berdasarkan gambar diatas terlihat bahwa nilai organoleptik bau ikan cakalang asap masih bagus pada penyimpanan 12 jam sesudah pengasapan kualitas ikan asap cukup baik yaitu nilai 7,3 , sesuai dengan Standar Nasional Indonesia (SNI 2725:2013) bahwa nilai organoleptik ikan asap pada lama penyimpanan minimal 7. Hasil anova (Lampiran 4) memperlihatkan nilai organoleptik bau ikan cakalang asap memiliki perbedaan yang signifikan berdasarkan lama penyimpanan. Hasil uji tukey (Lampiran 4) memperlihatkan bahwa kualitas ikan asap antar jam penyimpanan berbeda secara signifikan $\quad(p<0,05) \quad$ berarti setelah pengasapan kualitas ikan cakalang asap mengalami penurunan secara nyata.

3) Rasa 


\section{Jurnal IPTEKS PSP. Vol. 6 (11) April 2019:128-153}

Ikan cakalang asap sesudah pengasapan memiliki spesifikasi rasa yang enak. Cita rasa ikan asap menurun secara signifikan setelah proses pengasapan (Gambar 28).

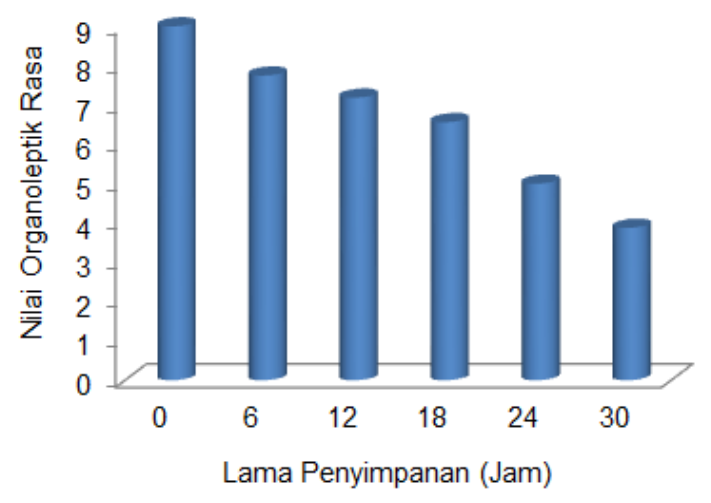

Gambar 28. Nilai organoleptik rasa ikan cakalang (Katsuwonus pelamis) bahan baku ikan asap

Nilai organoleptik rasa ikan cakalang asap masih bagus pada penyimpanan 12 jam sesudah pengasapan yaitu nilai 7,1 , sesuai dengan Standar Nasional Indonesia (SNI 2725:2013) bahwa nilai organoleptik ikan asap pada lama penyimpanan minimal 7 . Hasil anova (Lampiran 4) berdasarkan lama penyimpanan memperlihatkan bahwa nilai organoleptik rasa ikan cakalang asap memiliki perbedaan yang signifikan. Hasil uji tukey (Lampiran 4) memperlihatkan bahwa kualitas rasa ikan cakalang asap berbeda secara signifikan $(p<0,05)$ antar setiap jam penyimpanan yang berarti bahwa setelah pengasapan kualitas ikan cakalang asap mengalami penurunan secara nyata.

\section{4) Tekstur}

Tekstur daging pada ikan cakalang asap sesudah pengasapan memiliki spesifikasi tekstur yang padat, kompak, kering, dan antar jaringan yang erat. Tekstur daging ikan cakalang asap menurun secara signifikan setelah proses pengasapan (Gambar 35).

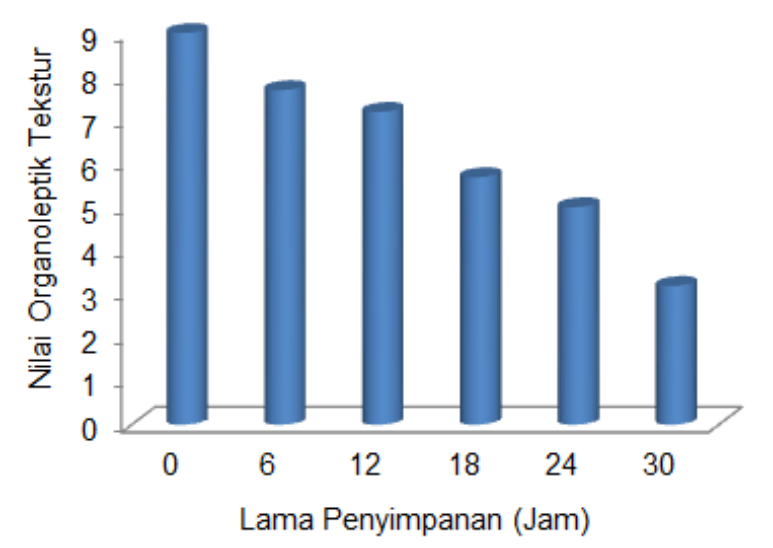

Gambar 29. Nilai organoleptik tekstur ikan cakalang (Katsuwonus pelamis) bahan baku ikan asap

Nilai organoleptik tekstur daging ikan cakalang asap masih bagus pada penyimpanan 12 jam sesudah pengasapan kualitas ikan asap cukup baik yaitu nilai 7,1, sesuai dengan Standar Nasional Indonesia (SNI 2725:2013) bahwa nilai organoleptik ikan asap pada lama penyimpanan minimal 7 . Hasil anova memperlihatkan nilai organoleptik tekstur ikan cakalang asap memiliki perbedaan yang signifikan berdasarkan lama penyimpanan. Hasil uji tukey memperlihatkan bahwa kualitas ikan asap antar jam penyimpanan berbeda secara 
signifikan $\quad(p<0,05) \quad$ berarti setelah pengasapan kualitas ikan cakalang asap mengalami penurunan secara nyata.

Data hasil uji mutu ikan cakalang (katsuwonus pelamis) asap bahwa kemunduran mutu terjadi secara terus menerus secara signifikan selama waktu penyimpanan produk ikan asap setelah proses pengasapan (Gambar 30).

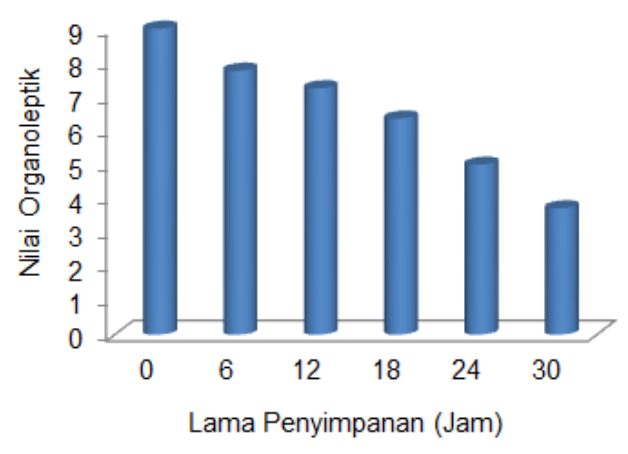

Gambar 30. Nilai rata-rata komponen organoleptik ikan cakalang (Katsuwonus pelamis) bahan baku ikan asap

Nilai organoleptik ikan cakalang asap masih bagus pada penyimpanan 12 jam sesudah pengasapan penyimpanan kualitas ikan cakalang yaitu nilai 7,2, sesuai dengan Standar Nasional Indonesia (SNI 2725:2013) bahwa nilai organoleptik ikan asap pada lama penyimpanan minimal 7. Hasil anova memperlihatkan nilai organoleptik ikan cakalang asap memiliki perbedaan yang signifikan berdasarkan lama penyimpanan. Hasil uji tukey (Lampiran 4) memperlihatkan bahwa kualitas ikan asap antar jam penyimpanan berbeda secara signifikan $(p<0,05)$ berarti setelah pengasapan kualitas ikan cakalang asap mengalami penurunan secara nyata.

\section{b. Ikan Tuna Sirip Kuning (Thunnus albacares)}

1) Kenampakan

Kenampakan pada ikan tuna sirip kuning asap sesudah pengasapan spesifikasi yang menarik, bersih, dan warna coklat. Parameter kenampakan menurun ke level tidak layak konsumsi setelah 18 jam selesainya proses pengasapan (Gambar 31).

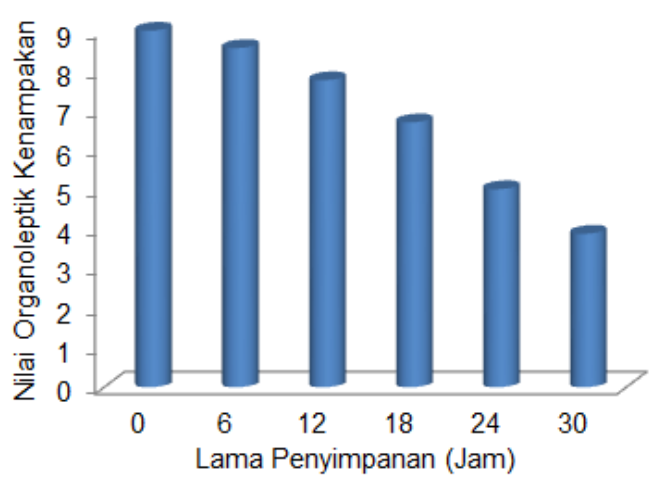

Gambar 31. Nilai organoleptik kenampakan ikan tuna sirip kuning (Thunnus albacares) bahan baku ikan asap

Berdasarkan gambar diatas, nilai organoleptik kenampakan ikan tuna sirip kuning asap masih bagus pada penyimpanan 12 jam sesudah pengasapan kualitas ikan asap yaitu nilai 7,7, sesuai dengan Standar Nasional Indonesia (SNI 2725:2013) bahwa nilai organoleptik ikan asap pada lama penyimpanan minimal 7. Hasil anova berdasarkan lama penyimpanan 
memperlihatkan bahwa nilai organoleptik kenampakan ikan tuna sirip kuning memiliki perbedaan yang signifikan. Hasil uji tukey (Lampiran 4) memperlihatkan bahwa kualitas ikan asap antar jam penyimpanan berbeda secara signifikan $(p<0,05)$ berarti setelah pengasapan kualitas ikan tuna sirip kuning asap mengalami penurunan secara nyata.

2) $\mathrm{Bau}$

Ikan tuna sirip kuning asap sesudah pengasapan memiliki spesifikasi bau yang harum dan tanpa bau tambahan mengganggu. Nilai organoleptik bau ikan asap masih memenuhi standar kelayakan konsumsi sampai 18 jam setelah proses pengasapan (Gambar 32).

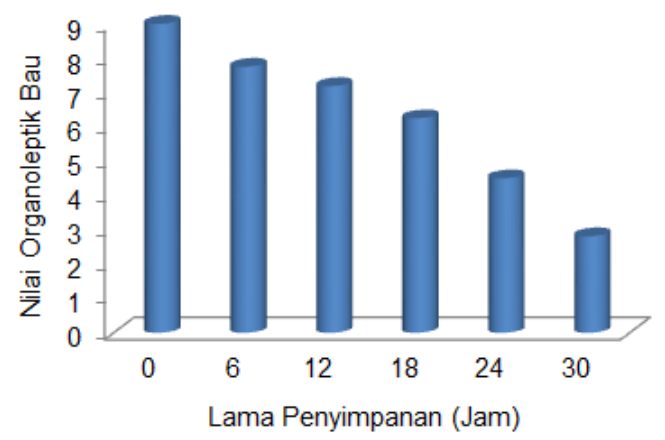

Gambar 32. Nilai organoleptik bau ikan tuna sirip kuning (Thunnus albacares) bahan baku ikan asap

Berdasarkan gambar diatas terlihat bahwa nilai organoleptik bau ikan tuna sirip kuning asap masih bagus pada penyimpanan 12 jam sesudah pengasapan kualitas ikan asap yaitu nilai 7,1 , sesuai dengan Standar Nasional Indonesia (SNI 2725:2013) bahwa nilai organoleptik ikan asap pada lama penyimpanan minimal 7. Hasil anova (Lampiran 4) memperlihatkan nilai organoleptik bau ikan tuna sirip kuning asap memiliki perbedaan yang signifikan berdasarkan lama penyimpanan. Hasil uji tukey (Lampiran 4) memperlihatkan bahwa kualitas ikan asap antar jam penyimpanan berbeda secara signifikan $(p<0,05)$ berarti setelah pengasapan kualitas ikan tuna sirip kuning asap mengalami penurunan secara nyata.

3) Rasa

Ikan tuna sirip kuning asap sesudah pengasapan memiliki spesifikasi rasa yang enak. Cita rasa ikan asap menurun secara signifikan setelah proses pengasapan (Gambar 33).

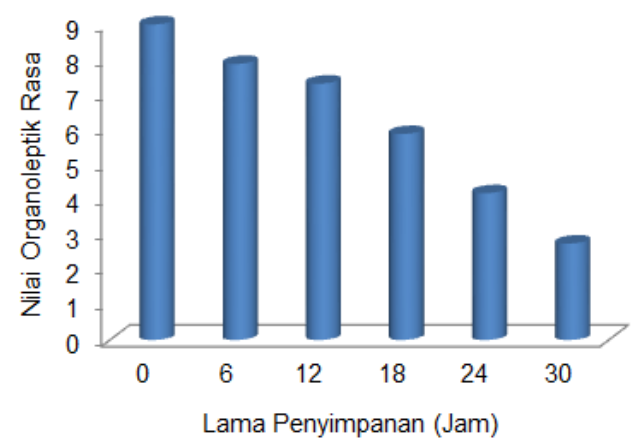

Gambar 33. Nilai organoleptik rasa ikan tuna sirip kuning (Thunnus albacares) bahan baku ikan asap

Nilai organoleptik rasa ikan tuna sirip kuning asap masih bagus pada penyimpanan 12 jam sesudah pengasapan kualitas ikan yaitu nilai 7,3 , sesuai dengan Standar 
Nasional Indonesia (SNI 2725:2013) bahwa nilai organoleptik ikan asap pada lama penyimpanan minimal 7. Hasil anova memperlihatkan bahwa nilai organoleptik pada setiap lama penyimpanan memiliki perbedaan yang signifikan. Hasil uji tukey memperlihatkan bahwa rasa ikan tuna sirip kuning asap berbeda secara signifikan $(p<0,05)$ antar setiap jam penyimpanan yang berarti bahwa setelah pengasapan kualitas ikan tuna sirip kuning asap mengalami penurunan secara nyata.

\section{4) Tekstur}

Tekstur daging pada ikan tuna sirip kuning asap sesudah pengasapan memiliki spesifikasi tekstur yang padat, kompak, kering, dan antar jaringan yang erat. Tekstur daging ikan tuna sirip kuning asap menurun secara signifikan setelah proses pengasapan (Gambar 34).

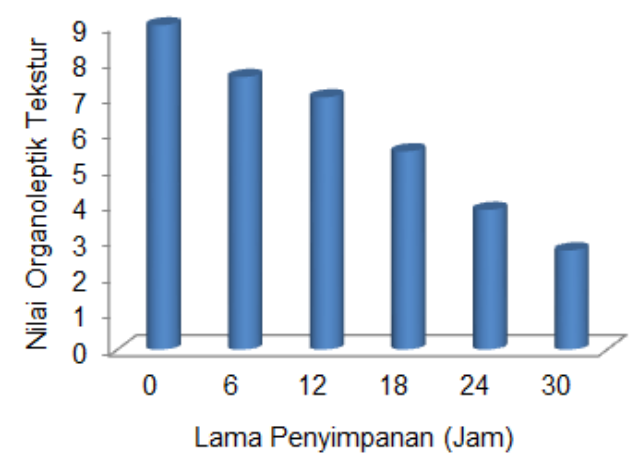

Gambar 34. Nilai organoleptik rasa ikan tuna sirip kuning (Thunnus albacares) bahan baku ikan asap

Nilai organoleptik tekstur daging ikan tuna sirip kuning asap masih bagus pada penyimpanan 12 jam sesudah pengasapan kualitas ikan asap yaitu nilai 7,0 , sesuai dengan Standar Nasional Indonesia (SNI 2725:2013) bahwa nilai organoleptik ikan asap pada lama penyimpanan minimal 7 . Hasil anova memperlihatkan nilai organoleptik tekstur ikan tuna sirip kuning asap memiliki perbedaan yang signifikan berdasarkan lama penyimpanan. Hasil uji tukey memperlihatkan bahwa kualitas ikan asap antar jam penyimpanan berbeda secara signifikan $\quad(p<0,05) \quad$ berarti setelah pengasapan kualitas ikan tuna sirip kuning asap mengalami penurunan secara nyata.

Data hasil uji mutu ikan tuna sirip kuning (Thunnus albacares) asap bahwa kemunduran mutu terjadi secara terus menerus secara signifikan selama waktu penyimpanan produk ikan asap setelah proses pengasapan (Gambar 35).

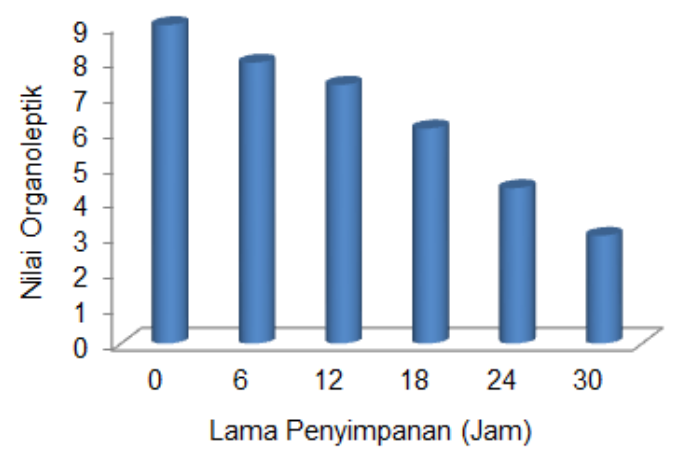

Gambar 35. Nilai rata-rata organoleptik ikan tuna sirip kuning (Thunnus albacares) bahan baku ikan asap

Nilai organoleptik ikan tuna sirip kuning asap masih bagus pada penyimpanan 12 jam 
sesudah pengasapan penyimpanan kualitas ikan tuna sirip kuning yaitu nilai 7,3 , sesuai dengan Standar Nasional Indonesia (SNI 2725:2013) bahwa nilai organoleptik ikan asap pada lama penyimpanan minimal 7 . Hasil anova memperlihatkan nilai organoleptik ikan tuna sirip kuning asap memiliki perbedaan yang signifikan berdasarkan lama penyimpanan.

\section{KESIMPULAN DAN SARAN}

Proses pengolahan ikan asap yang dilakukan oleh masyarakat di Desa Singadilakukan dengan terlebih dahulu memilih bahan baku, yang terdiri dari ikan cakalang dan tuna sirip kuning. Kemudian ikan yang telah disiapkan dipotong menjadi beberapa bagian, setelah itu ikan dilakukan pencucian ikan untuk menghilangkan lendir, darah, dan kotoran lainnya, kemudian ditiriskan selanjutnya ikan ditusuk agar pada saat diasapi ikan tidak rusak dan mudah dibolak balik, dan yang terakhir dilakukan pengasapan ikan dengan metode pengasapan panas yang dilakukan secara terbuka dan lama pengasapan yang singkat sehingga berpengaruh pada kualitas dan daya simpan produk.

Kualitas organoleptik bahan baku ikan cakalang dan tuna sirip kuning setelah dibeli dari penangkap/pelelangan dan sebelum diproses memiliki nilai 8,18 artinya mutu (sangat segar) sesuai dengan SNI 2729:2006, sedangkan kualitas organoleptik bahan baku ikan cakalang dan tuna sirip kuning sesudah pengasapan memiliki nilai 7,2 artinya mutu (segar) sesuai dengan SNI 2725:2013. Ikan cakalang dan tuna sirip kuning asap hanya dapat bertahan 18 - 20 jam disimpan pada suhu kamar, setelah itu produk sudah tidak layak konsumsi.

\section{DAFTAR PUSTAKA}

Adawyah, R. 2007. Pengolahan dan Pengawetan Ikan. Edisi Pertama. Bumi Aksara: Jakarta.

Adawiyah, R. 2008. Pengolahan dan Pengawetan Ikan. Ed 1. Bumi Aksara. Jakarta. 160 hal.

Adji, K. 2008. Evaluasi Kontaminasi Bakteri Pathogen Pada Ikan Segar di Perairan Teluk Semarang. Tesis: Universitas Diponegoro Semarang.

Afrianto, E. dan Liviawaty, E. 2005. Pengawetan dan Pengolahan Ikan. Kanisius, Yogyakarta.

BPS Kabupaten Bulukumba. 2017. Bulukumba Dalam Angka 2017. BPS Kab. Bulukumba: Bulukumba.

Departemen Kelautan dan Perikanan. 2007. Keputusan Menteri Kelautan dan Perikanan Republik Indonesia No. Kep. 01/Men/2007 Tentang Persyaratan Jaminan Mutu dan Keamanan Hasil Perikanan pada Proses Produksi, Pengolahan dan Distribusi. Jakarta: DKP. 
DKP Kabupaten Bulukumba. 2017. Laporan Dinas Kelautan dan Perikanan Kabupaten Bulukumba Tahun 2017. DKP Kabupaten Bulukumba: Bulukumba.

DKP Sulsel. 2002. Panduan Mutu Laboratorium Pembinaan dan Pengujian Mutu Hasil Perikanan. Dinas Kelautan dan Perikanan Sulsel. Makassar.

Grace, S. 2010. Oksidasi Lemak Ikan Tongkol yang Direndam Dalam Larutan Ekstrak Daun Sirih. Jurnal Pasific Vol.2 (5). Fakultas Perikanan dan Ilmu Kelautan, UNSRAT. Manado.

Hadiwoyo, S. 1993. Teknologi Hasil Perikanan Liberty. Yogyakarta

Heruwati, E.S. 2002. Pengolahan Ikan Secara Tradisional: prospek dan peluang. Pusat Riset Pengolahan Produk dan Sosial Ekonomi Kelautan dan Perikanan, Jakarta.

Kaparang, R. N. 2011. Penentuan Mutu Tandipang (Dussumieria Acuta C.V.) Asap Kering Selama Penyimpanan Suhu Kamar. Skripsi. Fakultas Perikanan Dan Ilmu Kelautan. UNSRAT. Manado.

Karyadi dan Sulistyowati. 2010. Usaha Meningkatkan Ketrampilan Kelompok Pengrajin Ikan Asap Melalui Pelatihan dan Pendampingan Dengan Memakai Rumah Asap Hasil Modifikasi. Sekolah Tinggi Ilmu Pertanian.

Kusmayadi, A dan Sukandar, D. 2007. Cara Memilih dan Mengolah Makanan Untuk Perbaikan Gizi Masyarakat. Special Programme For Food Security. Asia Indonesia, diakses 23 januari

2018,

(http://webmaster@deptan.go.id).

Linggarwati, E. D. 2016. Kandungan Protein dan Daya Terima Ikan Bandeng dengan Metode Pengolahan Pengasapan. Skripsi. Fakultas Perikanan dan Ilmu Kelautan. UNSRAT. Manado.

Mahmudy, B. M. Sahami, F. M. \& Nursinar, S. 2014. Pengaruh Lama Penyimpanan Terhadap Mutu Produk Ikan Cakalang (Katsuwonus Pelamis) Asap. Fakultas Perikanan dan Ilmu Kelautan.

Metusalach, Kasmiati, Fahrul, dan Ilham Jaya. 2012. Pengaruh Cara Penangkapan dan Cara Penanganan dengan Kualitas Ikan yang Dihasilkan. Jurnal IPTEKS PSP, Vol 1 (1) April 2014 14: $40-52$.

Murniyati dan Sunarman. 2000. Pengawetan Ikan dan Hasil Perikanan. CV. Arieka, Solo.

Nastiti, D. 2006. Kajian peningkatan mutu produk Ikan Manyung (Arius thalassinus) Panggang Di Kota Semarang. Tesis: Universitas Diponegoro Semarang.

Pranata, J. 2004. Pemanfaatan Sabut dan Tempurung Kelapa serta Cangkang Sawit untuk Pembuatan Asap Cair Sebagai Pengawet Makanan Alami. Skripsi. F-MIPA. Universitas Malikussaleh Lhokseumawe. Aceh.

Pranata, J. 2007. Pemanfaatan Sabut dan Tempurung Kelapa Serta Cangkang Sawit Untuk Pembuatan Asap Cair Sebagai Pengawet Makanan Alami. Tesis. Teknik Kimia 


\section{Jurnal IPTEKS PSP. Vol. 6 (11) April 2019: 128-153}

Universitas

Malikussaleh

Lhokseumawe. Aceh.

Purnomo dan Salasa. 2002. Teknologi Pengolahan Hasil Perikanan. Universitas Terbuka Jakarta.

Saanin, H. 1984. Taksonomi dan Kunci Identifikasi Ikan. Jilid I-II. Edisi II. Bina Cipta Bogor.

Simko, P. 2005. Detemination of polycyclic aromatic hydrocarbons in smoked meat products and smoke flavouring food additives. J. Chromatogr. 770: 3-18.

SNI 2346.1-2011. Uji Organoleptik Ikan Asap - Bagian 1: Spesifikasi. Badan Standarisasi Nasional Indonesia: Jakarta.

SNI 2725.1-2009. Ikan Asap - Bagian 1: Spesifikasi. Badan Standarisasi Nasional Indonesia: Jakarta.

SNI 2725.1-2013. Ikan Asap - Bagian 1: Spesifikasi. Badan Standarisasi Nasional Indonesia: Jakarta.

SNI 2729.1-2006. Uji Organoleptik Ikan Segar - Bagian 1: Spesifikasi. Badan Standarisasi Nasional Indonesia: Jakarta.

Suptijah, P. 2008. Kajian efek daya hambat kitosan terhadap mutu fillet ikan patin (Pangasius hypopthalmus) pada penyimpanan suhu ruang. Buletin Teknologi Hasil Perikanan. 11(2): 89-101.

Swastawati, 2012. Karakteristik kualitas ikan asap yang diproses menggunakan metode jenis ikan berbeda. International journal of Bioscience, Biochemistry and Bioinformatics Vol. 2 No. 3, October 2008: 212-216.
Tribowo, A. 1985. Pengaruh Penundaan Waktu Pengesan dan Lama Pengesan Bahan Mentah Terhadap Mutu Ikan Malalugis (Decapterus macrosoma) Asap Yang Disimpan Pada Suhu Kamar. Tesis. Fakultas Perikanan dan Ilmu Kelautan. Unsrat. Manado.

Widiastuti, I. M. 2007. Sanitasi dan mutu kesegaran ikan konsumsi pada pasar tradisional di Kotamadya Palu. Jurnal Agroland 14(1): 77-81.

Winarno, F. G. 1974. Kerusakan Bahan Pangan. Gramedia Utama, jakarta.

Winarno dan Sri Laksmi. 1983. Pengantar Teknologi Pangan. Gramedia. Jakarta.

Winarno dan Surono. 2004. GMP: Cara Pengolahan Pangan yang Baik. Cetakan ke 2. Bogor: M-BRIO Press.

Winarno, F. G. 2008. Kimia Pangan dan Gizi. Jakarta: Gramedia Pustaka Utama.

Wiryanti, J. dan Witjaksono, H.T. 2001. Konsepsi HACCP. Bumi aksara. Jakarta

Yuliawati, 2005. Kontaminasi Bakteri pada Ikan Asap di Sentra Industri Pengasapan Ikan dan Yang dijual di Pasar Kota Semarang. Universitas Diponegoro, Semarang. 